\title{
Fluid Inclusions and Metallogenic Conditions of the Dashuigou Tellurium Deposit, Tibet Plateau, Southwest China
}

\author{
Jianzhao Yin ${ }^{1 *}$ and Hongyun Shi \\ ${ }^{1}$ Ph.D., Orient Resources Ltd., Richmond, British Columbia, Canada V7E 1M8 \\ ${ }^{2}$ Ph.D., Bureau Veritas Commodities Canada Ltd., Richmond, BC, Canada V7A 4V5 \\ *Corresponding author: Jianzhao Yin, Ph.D, Orient Resources Ltd., Richmond, British Columbia, Canada V7E 1M8; Tel: 1-778-668.7717; Email: jimyin7@yahoo.ca
}

Received: May 11, 2021; Accepted: May 19, 2021; Published: May 27, 2021

\begin{abstract}
By thoroughly researching the microscopic characteristics and compositions of fluid inclusions in various minerals of the Dashuigou independent tellurium deposit in Southwest China, the authors of this paper uncover metallogenic conditions of the only independent tellurium deposit in the world. The principal compositions of the metallogenic hydrothermal fluids are $\mathrm{Na}^{+}, \mathrm{K}^{+}, \mathrm{Ca}^{2+}, \mathrm{Mg}^{2+}, \mathrm{SO}_{4}^{2-}, \mathrm{Cl}^{-}, \mathrm{F}^{-}, \mathrm{H}_{2} \mathrm{O}, \mathrm{CO}_{2^{\prime}} \mathrm{CH}_{4^{\prime}} \mathrm{H}_{2^{\prime}}, \mathrm{N}_{2^{\prime}} \mathrm{CO}$ and $\mathrm{C}_{2} \mathrm{H}_{6}$. The salinity of fluid inclusions within the metallogenic epochs varies between $13.8 \%-36.2 \%$, which falls into a medium-high salinity range. The salinity of quartz samples associated with tellurides formed during the tellurium epoch is $14.9 \%-18.7 \%$, which is within the medium salinity range. Metallogenic pressure is calculated at $0.647-1.020 \mathrm{Kbar}$, and the corresponding mineralization depth is $4.08-2.16 \mathrm{~km}$. Mineralization temperatures of the deposit's early and late metallogenic epochs are respectively 336.0-406.0 and 216.9-229.0 ${ }^{\circ} \mathrm{C}$. The metallogenic hydrothermal solutions are $\mathrm{SO}_{4}^{2-}-\mathrm{Ca}^{2+}$ type, or $\mathrm{SO}_{4}^{2--}-\mathrm{Na}^{+}-\mathrm{K}^{+}-\mathrm{Ca}^{2+}$ type, especially during the early Pyritic Epoch, and $\mathrm{Na}^{+}-\mathrm{K}^{+}-\mathrm{Cl}^{-}-\mathrm{SO}_{4}^{2-}$ type during the late metallogenic epoch. The metallogenic hydrothermal solutions of the deposit are of moderate salinity, mesothermal and mesogenetic.
\end{abstract}

Keywords: Metallogenic condition; Fluid inclusion; Homogenization temperature; Decrepitation temperature; Metallogenic epoch; The Dashuigou tellurium deposit; Tibet Plateau

\section{Introduction}

Tellurium (Te) is usually categorized as a scattered or dispersed element (abbreviated as SM). SM are those metals, semimetals and/ or nonmetals that have similar geochemical characteristics with Clark values too low to enrich into independent deposits, but that play very important roles in modern science, industry, national defense and at the frontiers of technology. It is thought in the traditional theory of mineral deposits and geochemistry that Te could not form independent deposits, but only exist as associated components in other metallic deposits. The abundance of Te in the Earth's Crust is very low. According to $\mathrm{Li}[1]$, the average content of Te in the Earth's crust is 2.0 $\times 10^{-8}$ in China, and only $1.34 \times 10^{-9}$ worldwide. At present, the world's supply of refined tellurium is mainly recovered from Te-bearing minerals including pyrite, sphalerite, chalcopyrite, galena, pyrrhotite, volcanogenetic sulfur, bismuthinite, arsenopyrite, and cassiterite, etc. Generally speaking, only sulfide ores containing more than $0.002 \%$ Te can be used. As a result, the amount of refined tellurium that can be recovered is very limited. Most of the recoverable Te in the world is from copper deposits, and it is estimated that only $0.065 \mathrm{~kg}$ of Te can be produced in the refining process of one ton of copper [2,3]. The Dashuigou tellurium deposit is the only independent tellurium deposit in the world. Since its discovery in 1992, it has aroused widespread concern from domestic geologists. Chen [4] believed that tellurium mineralization is related to Yanshanian alkaline intrusive rocks, while Luo $[5,6]$ believed that the mineralization is related to Yanshanian granitic magma activity. Yin $[3,7,8]$ proposed that scattered elements including tellurium and bismuth originated from gas blown off from the deep Earth and enriched through nano-effect. Wang [9] summarized the metallogenic process of the Dashuigou tellurium deposit as follows: a volcanic eruption deposit was formed on the ancient seafloor with magmatic eruption in the late Proterozoic. Then, the deposit was strongly superimposed and reconstructed by the Mesozoic multistage regional metamorphic hydrothermal activities.

\section{Regional Geology}

The Dashuigou tellurium deposit is located in the transitional belt between the Yangtze Platform and Songpan-Ganzi folded belt, as part of the Tibetan Plateau (Figure 1). The deposit is nestled in the convergence between the Indian, Eurasian and Pacific Plates. The crust-mantle structures and properties in the region are the result of tectogenesis through various geological times. It implies the turning boundary of the Earth's crust's thickness. It is also a gravity gradient zone which controls not only the production and development of earthquakes and tectonomagmatic events, but also the distribution of a series of mineral deposits. Geophysical data indicates that the upper mantle below the region uplifts obviously. As a result, the area possesses high heat flow geophysical characteristics $[3,5,6,10,11]$. 


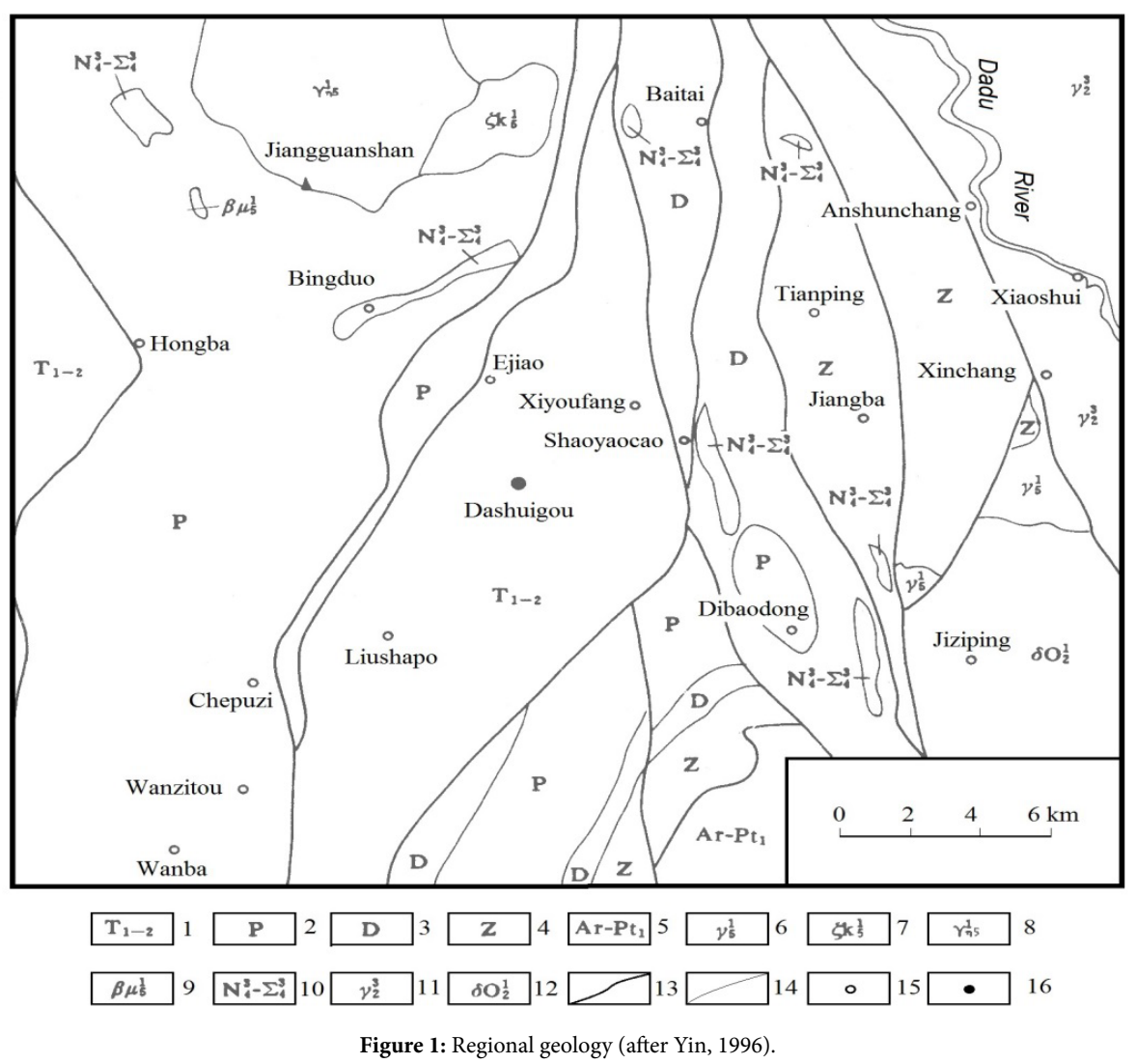

1. The lower and middle Triassic metamorphic rocks; 2. The Permian metamorphic rocks; 3 . The Devonian metamorphic rocks; 4. Metamorphic rocks of the Sinian system; 5. Metamorphic base complex of the Archean Kangding group; 6. Plutonic granite of the Indosinian orogeny; 7. Plutonic alkaline syenite of the Indosinian orogeny; 8. Plutonic monzonitic granite of the Indosinian orogeny; 9. Hypabyssal sillite of the Indosinian orogeny; 10. The late Hercynian basic-ultrabasic rocks; 11 . The late Proterozoic plutonic granite; 12. The early Proterozoic-Archean plutonic quartz diorite; 13 . The deep and large fault; 14 . The geological boundary; 15. Village and/ or town; 16 . The tellurium deposit. There is also a low-velocity, low resistivity zone in the middle crust that is interpreted as a decollement. The abnormal mantle exists under the crust in the region. It has properties of both geosyncline and platform, as well as its own special characteristics. The belt is a geo-tectonically active zone with very complicated igneous rock structures. According to the regional geophysical data, the region's characteristics exhibit high velocity, high density, high resistance, high geothermal flow, high magnetism as well as well-developed earthquakes and mantle's uplift. In summary, this region is both geologically very active and a very important southnorth trending tectonomagmatic-mineral belt [3-6]. The strata, igneous rocks and structures trend south-northward. The strata are low-grade metamorphic rocks of the Silurian, Devonian, Permian systems and middle-lower Triassic series. A large amount of Archaean metamorphic rocks of the Kangding Group emerge to the southeast of the deposit. The well-developed igneous rocks in the region include ultrabasic, basic, neutral, acid and alkaline, produced in different geological times. Different types of mineral resources in the region are very rich; many of these are well known, including $\mathrm{Ti}, \mathrm{V}, \mathrm{Cu}, \mathrm{Pb}$, $\mathrm{Zn}, \mathrm{SM}, \mathrm{REE}$, coal, asbestos and the Panzhihua Vanadium Titanomagnetite deposit [3-6].

\section{Mine Geology}

The strata of the area are low-grade metamorphic rocks of the lower-middle Triassic age, including marble, slate and schist. The main wall-rocks of the ore bodies are schist and slate. All of the Triassic strata make up a NNE-trending dome. The geological and geochemical characteristics in the area indicate that the protolith of the tellurium ore veins' direct wall-rocks is poorly differentiated mantle-derived basalt (Figure 2).

Both faults and folds are well-developed in the area. The annular and linear structures together make up special " $\varnothing$ " pattern structures, which control the formation of different types of endogenetic mineral deposits, including the Dashuigou tellurium deposit. No intrusive rocks emerge within a $5 \mathrm{~km}$ radius around the deposit. Only two small Permian ultrabasic-basic rock bodies emerge within a 10 $\mathrm{km}$ range of the deposit. Large neutral, acid and alkaline intrusive bodies exist beyond $10 \mathrm{~km}$, which are unrelated to the deposit (Figure 1). Quantitative chemical analyses of Te, Bi, Se, As, Au, Ag, $\mathrm{Cu}, \mathrm{Pb}$ and $\mathrm{Zn}$ were conducted on different rock samples including granites, metamorphic rocks, altered rocks, and carbonate veins of different geological times. The main findings are summarized below $[3,12-15]$. The Te content in the granites is under $1 \times 10^{-7}$, which is similar to its Clark value in the Earth's crust. Te in the metamorphic rocks is slightly higher than in the granites and varies slightly 


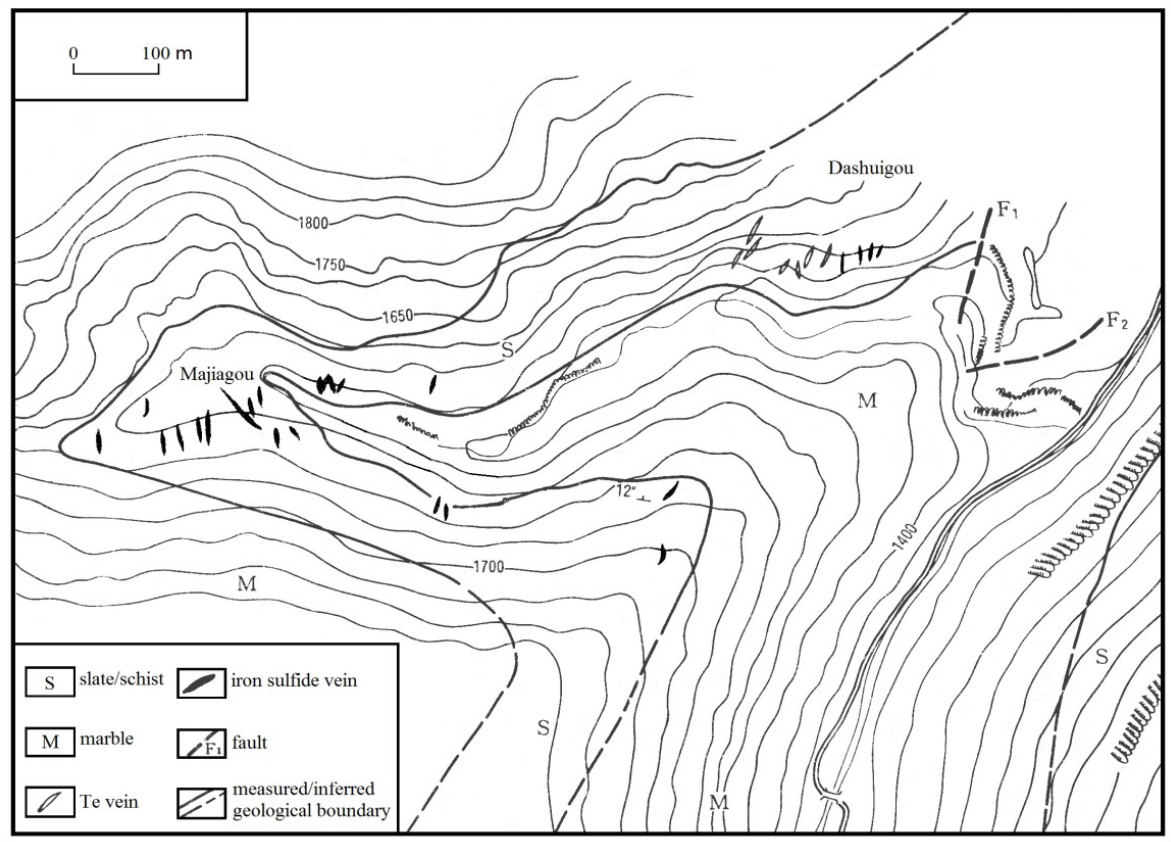

Figure 2: Mine geology (after Yin, 1996).

between metamorphic rocks of different geological times, while being relatively higher in the Triassic metamorphic rocks. Of the metamorphic rocks in the same geological time, the Te content in the slate and schist is higher than in the marble. Te content in rocks of the same stratohorizon of the same geological time also varies; namely, it is higher in rocks within the mining area than in those beyond the mining area. Te content is closely related to the intensity of alterations; that is, the ore-forming elements are not derived from the country rocks, but instead from the mantle. The deposit is located at the northeastern end of the Triassic metamorphic dome. The ore bodies are controlled by and fill a group of shear fractures. Ten tellurium ore veins have been discovered, which strike from 350 to 10 degrees and dip at 55 to 70 degrees westward. Widths of the ore bodies vary between 25 and $30 \mathrm{~cm}$. The narrow ore bodies are in the shape of lenticular veins and have sharp contact with the wall rocks (Figures 3 and 4).

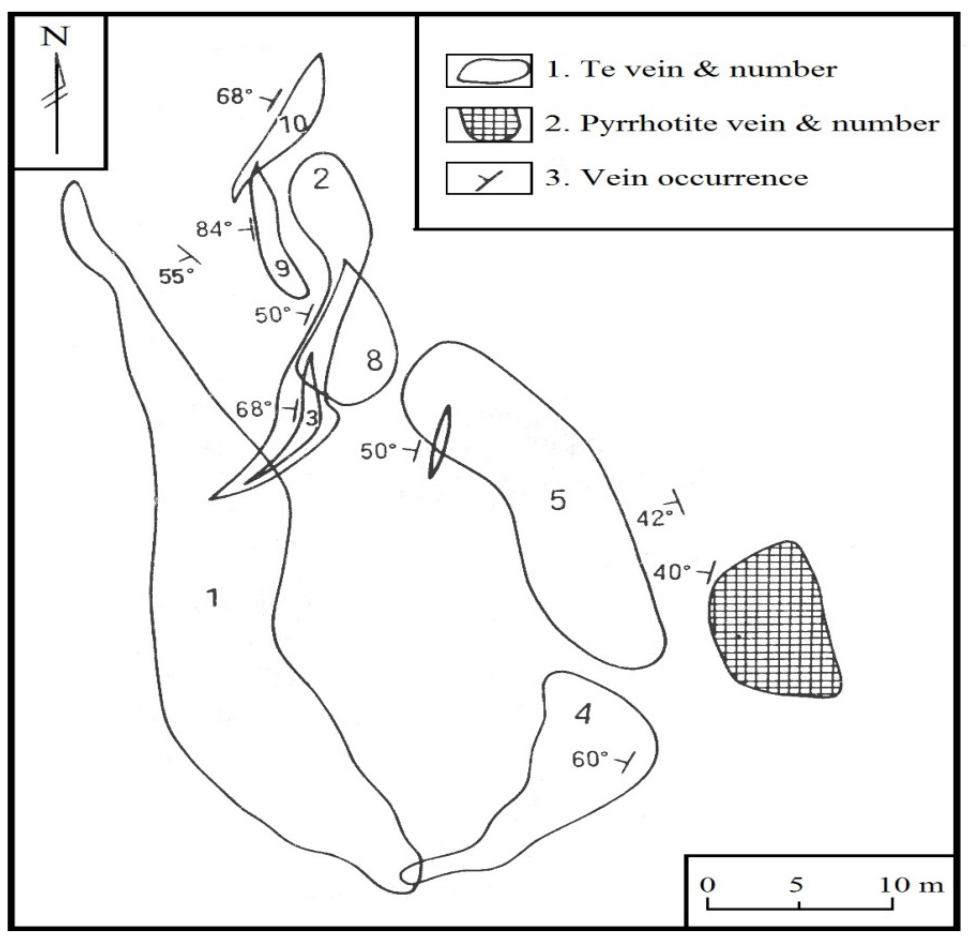

Figure 3: Horizontal projection of the telluride veins of the Dashuigou deposit (after Yin, 1996). 


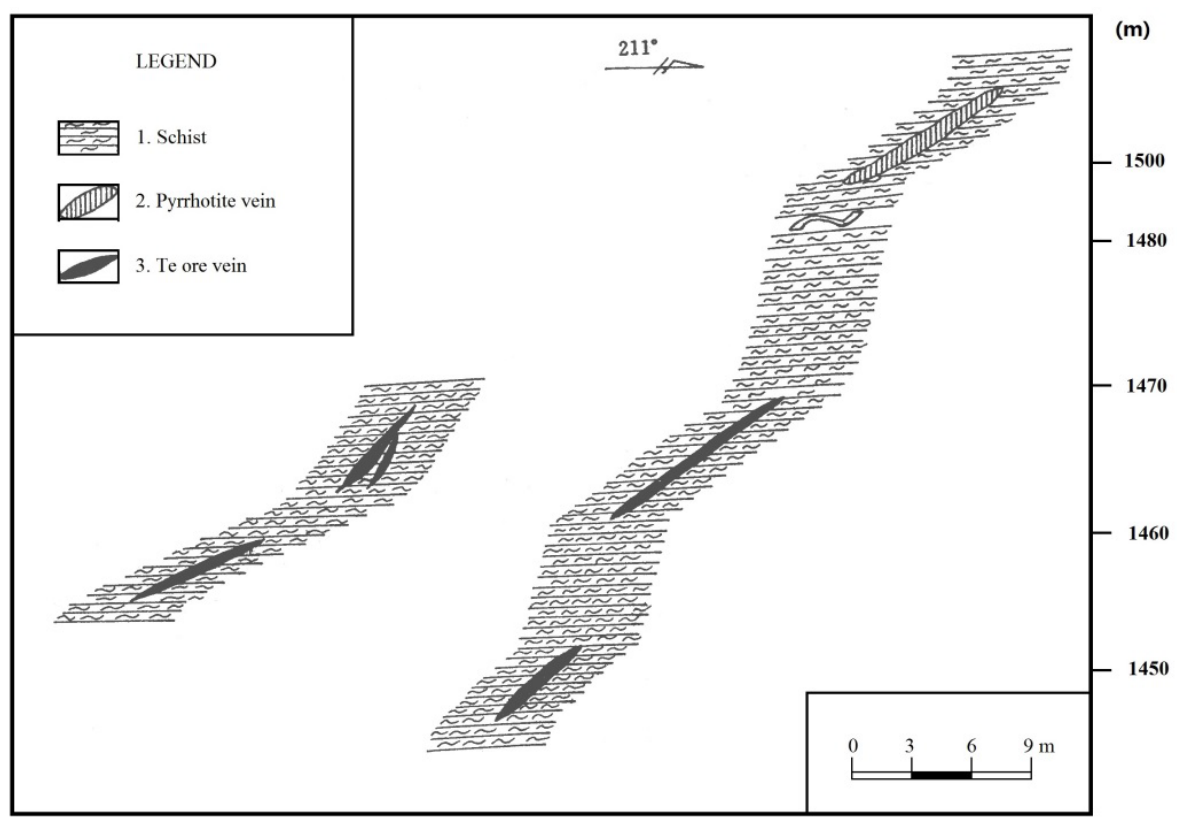

Figure 4: Longitudinal section the telluride and pyrrhotite veins of the Dashuigou deposit (after Yin, 1996).

The altered rocks occur in narrow bands ranging between several centimeters and one meter in thickness. Altered zones beside the massive ore veins are narrower, at only several centimeters wide. The dominant alterations include dolomitization, silicification, biotitization, muscovitizaion, tourmalinization, sericitizaion, greisenization, and chloritization [3,7,14-20]. Approximately thirty minerals are identified in the ore, which include tetradymite, pyrrhotite, pyrite, dolomite, quartz, chalcopyrite, tsumoite (BiTe), tellurobismuthite $\left(\mathrm{Bi}_{2} \mathrm{Te}_{3}\right)$, galena, magnetite, gold, silver, electrum, ilmenite, calcite, calaverite, siderite, mannesite, rutile, muscovite, biotite, sericite, hornblende, chlorite, plagioclase, K-feldspar, tourmaline, hematite, garnet, apatite, and epidote. The first five minerals are the most important and comprise $85 \%$ of the ore, though generally tetradymite is so rare that many monographs on mineralogy do not have any related data on it $[3,10,19-22]$. Replacement, remnant, reaction border, and granular are the dominating textures of the ore. Massive, vein/veinlet, stockwork veins are the dominating structures of the deposit (Figures 5 and 6).

The most important ores are massive and the secondary ores are disseminated. The Te content in the ore varies between $0.01 \%$ and $34.58 \%$.

Two mineralization epochs and five stages exist in the deposit $[3,8,23]$ :

- Pyrrhotite epoch (177.7 165.1 Ma): including three mineralization stages: carbonate stage (I) $\rightarrow$ pyrrhotite stage (II) $\rightarrow$ chalcopyrite stage (III) (from early to late).

- Tellurium epoch (91.71 80.19 Ma): including two mineralization stages, namely: tetradymite stage (I) $\rightarrow$ tsumoite $\left(\mathrm{BiTe}_{0.97}\right)$ stage (II).

\section{Mineralization Epoch and Mineral Sequence}

Based on the mutually crosscutting relationships of various veins/ veinlets in the deposit, including those of pyrrhotite, chalcopyrite, tetradymite, tsumoite, dolomite and quartz, in addition to the features of microscopic texture and structure between gangue and ore minerals, the mineralization epochs and stages as well as mineral sequence are summarized in Figure 7 [3,8,23].

\section{Carbonate Stage}

A large quantity of iron-dolomite, quartz and lesser calcite veins/ veinlets occurred within this stage, which are brown and/or yellowish brown broken coarse-grained due to iron staining (Figures 5 and 6). Decrepitation temperatures of the fluid inclusions in the dolomite, one of the dominant minerals of this stage, are listed in the corresponding table of this paper.

\section{Pyrrhotite Stage}

The largest quantity of pyrrhotite formed during this stage. Some coarse- to very coarse-grained pentagonal pyrite can be seen in the anhedral crystals of pyrrhotite. Decrepitation temperatures of the fluid inclusions in both the pyrrhotite, one of the dominant minerals, and pyrite of this stage are listed in the corresponding table of this paper.

\section{Chalcopyrite Stage}

Many chalcopyrite veins/veinlets formed within this stage, filling in fractures of pyrrhotite and/or crosscutting pyrrhotite. Part of the chalcopyrite is within telluride minerals in the vermicular form. Decrepitation temperatures of the fluid inclusions in the chalcopyrite, the dominant mineral of this stage, are listed in the corresponding table of this paper. 


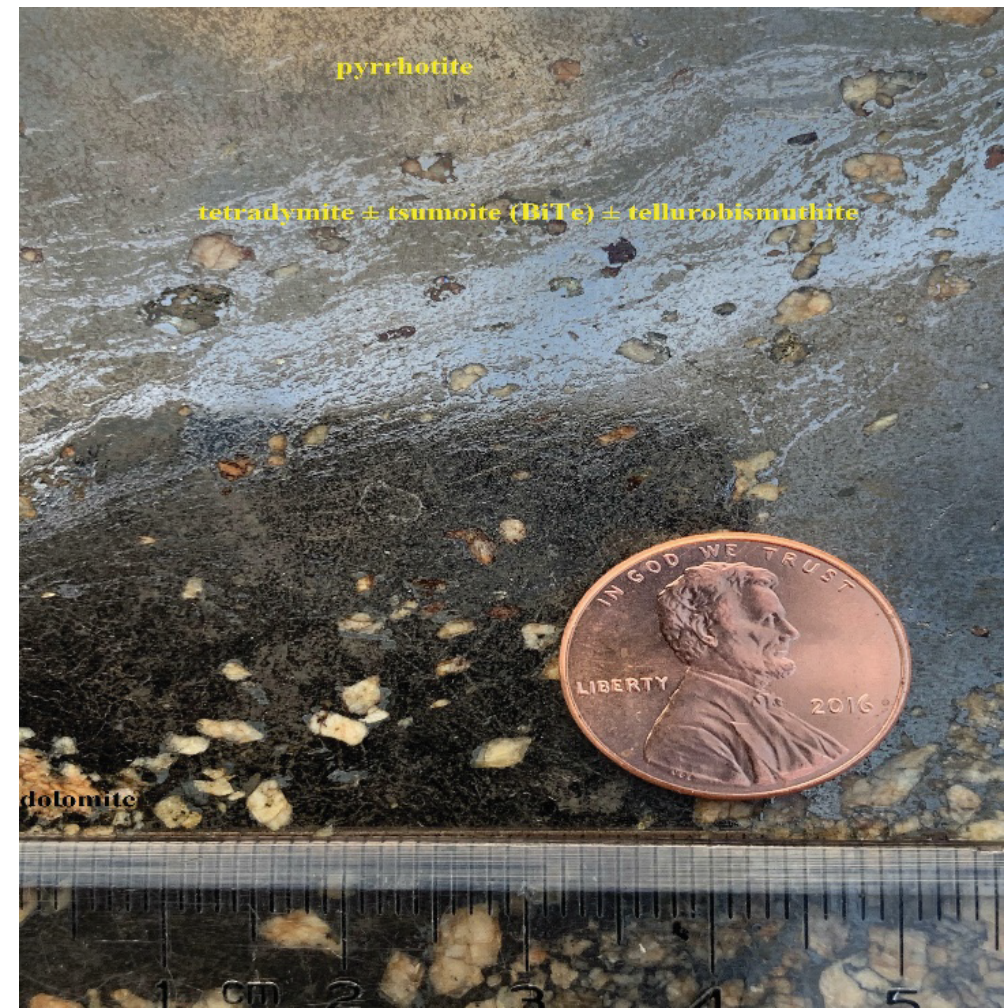

Figure 5: Lead grey-silvery colored tetradymite \pm tsumoite $(\mathrm{BiTe}) \pm$ tellurobismuthite $\left(\mathrm{Bi}_{2} \mathrm{Te}_{3}\right)$ fine veinlets in massive pyrrhotite (dark colored background) + dolomite (brownish white) from the deposit (sample \#: SD40, Ore body \#I-1 in Drift 3).

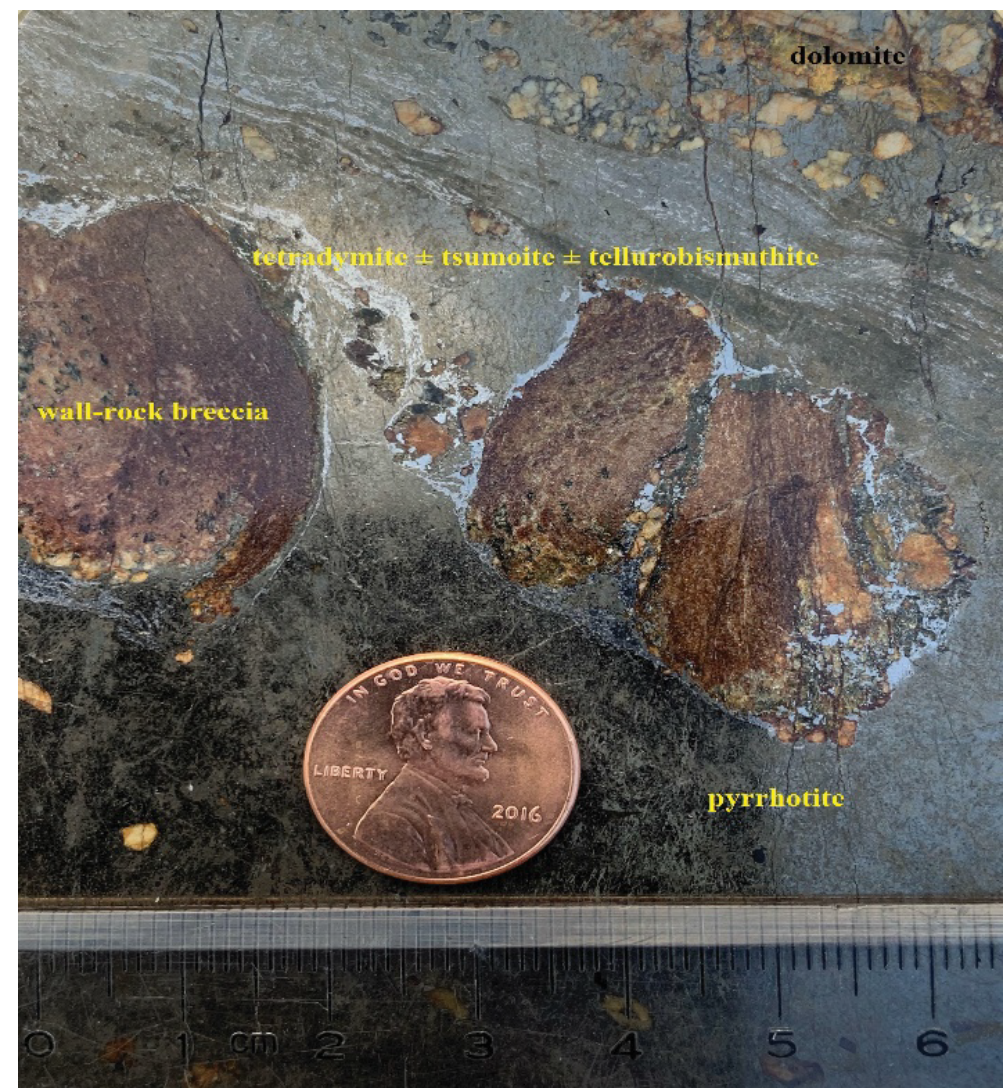

Figure 6: Lead grey-silvery colored tetradymite \pm tsumoite $(\mathrm{BiTe}) \pm$ tellurobismuthite $\left(\mathrm{Bi}_{2} \mathrm{Te}_{3}\right)$ fine veinlets in massive pyrrhotite (dark colored) + dolomite (brownish white) + wall rock (dark brown) from the deposit (sample \#: SD34, Ore body \#I-1 in Drift 3). 


\begin{tabular}{|c|c|c|c|c|c|}
\hline Metallogenic epoch & \multicolumn{3}{|c|}{ Pyritic Epoch (177.7-165.1 Ma) } & \multicolumn{2}{|c|}{ Tellurium Epoch (91.71-80.19 Ma) } \\
\hline $\begin{array}{c}\text { Mineralization stage } \\
\text { Mineral sequence }\end{array}$ & Carbonate Stage & Pyrrhotite Stage & Chalcopyrite stage & Tetradymite Stage & Isumoite Stage \\
\hline dolomite & $\longrightarrow$ & & & & \\
\hline \multicolumn{6}{|c|}{$\Longrightarrow$} \\
\hline quartz & $\longrightarrow$ & & & & \\
\hline \multicolumn{6}{|c|}{$=$} \\
\hline pyrite & $\Longrightarrow$ & $\Longrightarrow$ & & & \\
\hline \multicolumn{6}{|l|}{ pyrrhotite } \\
\hline chalcopyrite & & & 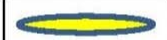 & $\Longrightarrow$ & $=$ \\
\hline muscovite/sericite & & & & $\Longrightarrow$ & \\
\hline tetradymite & & & & $\longrightarrow$ & \\
\hline tsumoite & & & & & $\longrightarrow$ \\
\hline native gold & & & $\Longrightarrow$ & $\infty$ & $\Longrightarrow$ \\
\hline \multicolumn{6}{|l|}{ native silver } \\
\hline \multirow{2}{*}{ temperature $\left({ }^{\circ} \mathrm{C}\right)$} & 360.8 & \multirow{2}{*}{$(366,0-406.0)^{* * * * *}$} & 336.0 & 229.0 & $\underline{216.93}$ \\
\hline & $(195.5-522.4)^{*}$ & & $(298.0-363.0)^{\text {**** }}$ & $(186.0-255.0)^{* * *}$ & $(180.0-258.8)^{*}$ \\
\hline
\end{tabular}

Figure 7: Mineralization epochs \& stages and mineral sequence of the deposit.

Note: ${ }^{*}$ - mineral inclusion homogenization temperature (dolomite for carbonate stage, quartz for tsumoite stage), please refer to Tables 1 and 2 for more detailed information; ${ }^{\star *}$ - mineral inclusion decrepitation temperatures of the corresponding stages (that of the pyrrhotite stage is the average of decrepitation temperatures of both the pyrite and pyrrhotite of the pyrrhotite stage.

The three prior mineralization stages consist of the early metallogenic epoch of the deposit, the pyritic epoch (177.7-165.1 Ma) of the early Yanshan orogeny. The following two mineralization stages consist of the tellurium metallogenic epoch (91.71-80.19 Ma) of the late Yanshan orogeny [3,24].

\section{Telluride Stage}

Large quantities of massive/semi-massive telluride veins formed during this stage, associated with clean, milky-white quartz, dolomite, calcite, muscovite/sericite and native gold. Decrepitation temperatures of the fluid inclusions in the tetradymite, the dominant mineral, and part of the associated dolomite of this stage are listed in the corresponding table of this paper.

\section{Tsumoite Stage}

Tsumoite and chalcopyrite together consist of emulsion droplets and/or vermicular immixing of solid solution texture at the contacts between tetradymite and pyrrhotite (Figures 5, 6 and 8).

The mineralization temperatures of this stage shown in Figure 7 are based on the homogenization temperatures of the fluid inclusions in the quartz associated with tsumoite. Please refer to the corresponding table of this paper for more detailed information.

\section{Sampling and Analytical Methodology}

\section{Field Sampling}

Samples were collected from proper locations of the deposit's typical ore bodies and wall rocks in the study area. They were described in detail on site, then properly labeled or numbered and wrapped with waxed paper to avoid cross contamination with other samples in the same sample box, and finally packed and shipped to the work laboratory.

\section{Lab Sampling and Preliminary Processing}

In the lab, all samples were sorted, air-dried, stage crushed to 6-Tyler mesh, well homogenized, and then rotary split into $1 \mathrm{~kg}$ assay aliquots. One assay aliquot was wet screened into different sized fractions, and the -10 mesh +65 mesh fraction was used for this study. After being crushed and screened through different sizes of mesh, the corresponding minerals in fraction from 10 to 65 mesh to be used for further analyses were then manually separated and picked up under binocular microscope, and their crystal forms and other physical mineralogical characteristics were observed and described in detail. Next, the selected mineral samples were pulverized to $90 \%$ passing $75 \mu \mathrm{m}$ for further research and testing, in order to help reveal the mineralization mechanism of the corresponding deposit.

\section{Analytical Methodology}

The gaseous components of the fluid inclusions in quartz were analyzed via both the Raman spectroscopy and gas chromatographic methods. The Raman spectroscopy technique has a wide field of applications, ranging from qualitative detection of solid, liquid and gaseous components to identification of polyatomic ions in solution. It is also a versatile non-destructive technique for fluid inclusion analysis and is commonly used to calculate the density of $\mathrm{CO}_{2}$ fluids, the chemistry of aqueous fluids, and the molar proportions of gaseous mixtures present as inclusions... The main advantages of this technique are the minimal sample preparation required and its high versatility. The particle size of the $99.9 \%$ purity mineral samples was controlled to $0.5-1.0 \mathrm{~mm}$ to avoid damaging the fluid inclusions. According to 

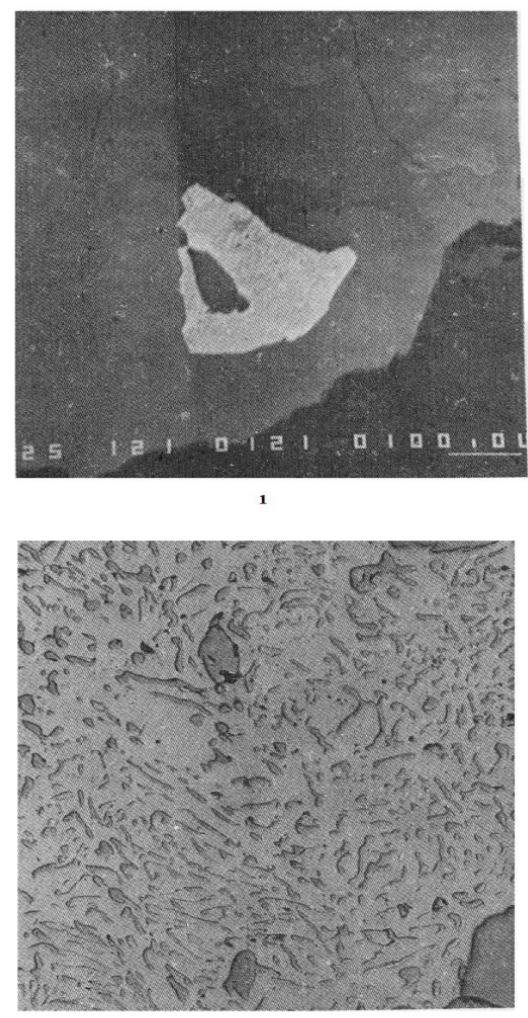

3
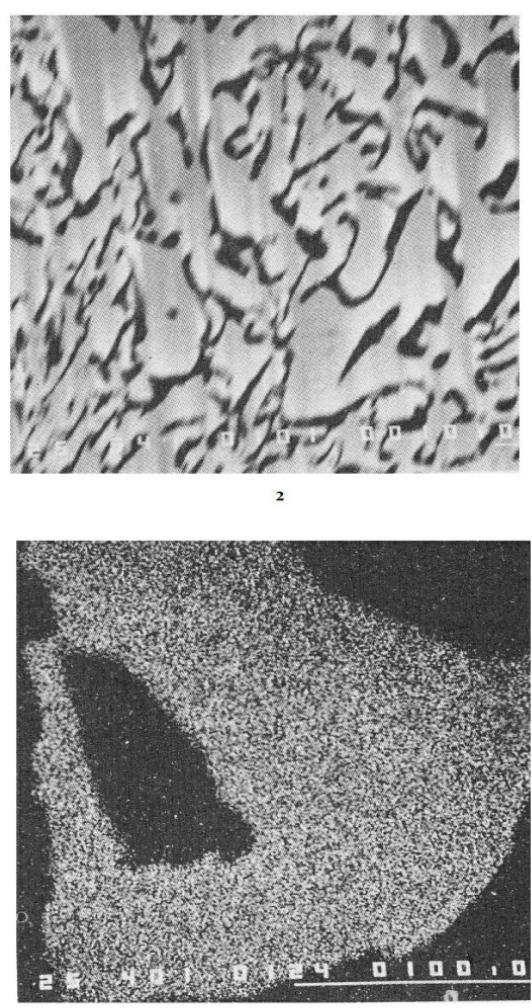

Figure 8: 1 3: Reflection color and their mutual relationships between tsumoite (bright white), tetradymite (white), and pyrrhotite (grey) in the back scattered electron (composition) image from the deposit (thin section (-) (Note: $1(\times 120), 2(\times 540), \& 3(\times 200)$ ). 4: Te Ka X ray image indicating chemical composition distributions of telluride including tetradymite and tsumoite (white): the denser the white spots, the higher the Te content; the black colored background is pyrrhotite from the deposit $(\times 400)$.

their respective burst temperatures, the primary inclusions in the minerals were opened by thermal explosion, and the fluid components obtained by heat-blast-leaching. The released gas-phase components such as $\mathrm{H}_{2} \mathrm{O}, \mathrm{CO}_{2}, \mathrm{CO}, \mathrm{H}_{2}, \mathrm{~N}_{2}$, and $\mathrm{CH}_{4}$ were measured by gas chromatography. Decrepitated mineral was added with deionized water, and ultrasonic extraction was then conducted. The extract liquor was measured by atomic absorption spectrometer for $\mathrm{K}^{+}, \mathrm{Na}^{+}$, $\mathrm{Ca}^{2+}, \mathrm{Mg}^{2+}$ and other cationic components in the solution, while anion components such as $\mathrm{F}^{-}, \mathrm{Cl}^{-}, \mathrm{SO}_{4}^{2-}$, etc. were determined through ion chromatography or spectrophotometry. In addition, $\mathrm{Fe}, \mathrm{Cu}, \mathrm{Pb}, \mathrm{Zn}$, $\mathrm{Sb}, \mathrm{Hg}, \mathrm{Au}, \mathrm{Ag}$ and other related ore-forming metal elements can be determined by the atomic absorption flameless method as required. Then, the gas and liquid phase components in the mineral inclusions were converted into the mass concentration of each component contained in the mineral inclusion aqueous solution. Conversion of liquid components: At room temperature, $1 \mathrm{ml}$ of water weighs about 1 gram. First, the mass of water in the analysis result is converted into the volume $V_{\mathrm{H} 2 \mathrm{O}}$, and the mass concentration $\rho_{\mathrm{B}}$ of each ion in the inclusion water is calculated via the following formula $[25,26]$ :

The volume of inclusion water $V_{\mathrm{H} 2 \mathrm{O}}=\omega_{\mathrm{H} 2 \mathrm{O}} / 1000$. Mass concentration of ions in liter of water $\rho_{\mathrm{B}}=\omega_{\mathrm{B}} / V_{\mathrm{H} 2 \mathrm{O}}$.

For the measurement data of vapor phase components $\mathrm{H}_{2} \mathrm{O}, \mathrm{CO}_{2}$, $\mathrm{CO}, \mathrm{H}_{2}$, and $\mathrm{CH}_{4}$, a relevant diagram [27] was applied to estimate the temperature, pressure, oxygen fugacity, carbon dioxide fugacity, reduction coefficient, and other geochemical parameters such as $\mathrm{pH}$ and Eh of the equilibrium among the components in the mineral inclusions.

\section{Characteristics of the Fluid Inclusions}

\section{General Characteristics}

The fluid inclusion characteristics of part of the deposit's gangue and ore minerals are summarized in Tables 2 and 3 and discussed as follows. Fluid inclusions are well developed in most of the deposit's minerals, but their characteristics differ from each other within different host minerals. Dolomite usually has less liquid inclusions than both calcite and quartz. The sizes of fluid inclusions in dolomite and calcite are usually between 3-5 $\mu \mathrm{m}$, which is smaller than those in quartz, which is usually 5-10 $\mu \mathrm{m}$ (Table 2). Fluid inclusions in both dolomite and calcite are mainly liquid and usually scattered without any orientation in mineral distribution, with a gas-liquid ratio of less than $5 \%$. Those in quartz, which are mainly gaseous-liquid inclusions within the deposit, are more complicated than those in both dolomite and quartz; either scattered without any orientation in distribution, or in zonal distribution in certain orientations (Figure 6). Fluid inclusions in the tourmaline-quartz vein collected from the periphery of the deposit are mainly gaseous-liquid inclusions and differ from those of quartz within the deposit; a few 3 phase inclusions could be seen in the quartz vein collected around the deposit. 
Jianzhao Yin (2021) Fluid Inclusions and Metallogenic Conditions of the Dashuigou Tellurium Deposit, Tibet Plateau, Southwest China

Table 1 : Decrepitation temperatures of fluid inclusion in the minerals from the deposit.

\begin{tabular}{|c|c|c|c|c|c|c|}
\hline series \# & sample \# & mineral & location & test results $\left({ }^{\circ} \mathrm{C}\right)$ & & \\
\hline & & & & principal value & reference value & average \\
\hline 1 & SD-10 & pyrrhotite & Pyr vein between \# II \& III Ore Zones & 387 & 64 & \\
\hline 2 & SD-15 & & Pyr vein of \# III Ore Zone & 325 & 125 & \\
\hline 3 & SD-16 & & \#III-2 Pyr vein & 423 & $\mathrm{n} / \mathrm{a}$ & \\
\hline 4 & SD-23 & & Pyr vein within \# I-4 Ore Vein & 447 & $\mathrm{n} / \mathrm{a}$ & \\
\hline 5 & SD-29 & & Pyr vein within \# I-5 Ore Vein & 422 & $\mathrm{n} / \mathrm{a}$ & 406 \\
\hline 6 & SD-41 & & Pyr vein within \# I-1 Ore Vein & 420 & $\mathrm{n} / \mathrm{a}$ & $(325-447)$ \\
\hline 7 & SD-55 & & Pyr vein within \# I-10 Ore Vein & 444 & 145 & \\
\hline 8 & SD-65 & & Pyr vein within \# I-8 Ore Vein & 387 & $\mathrm{n} / \mathrm{a}$ & \\
\hline 9 & SD-71 & & Pyr vein within \# I Ore Zone & 401 & $\mathrm{n} / \mathrm{a}$ & \\
\hline 10 & SL-06 & pyrite & from a QV outside the mine & $207(\mathrm{~L})$ & $\mathrm{n} / \mathrm{a}$ & \\
\hline 11 & SL-10 & & from Permian metamorphosed basalt & $\mathrm{n} / \mathrm{a}$ & $\mathrm{n} / \mathrm{a}$ & \\
\hline 12 & SD-17 & & from Pyr vein within III-2 Ore Vein & $332(\mathrm{E})$ & $\mathrm{n} / \mathrm{a}$ & \\
\hline 13 & SD-23 & & from \#I-4 Ore Vein & $396(\mathrm{E})$ & $\mathrm{n} / \mathrm{a}$ & $366(\mathrm{E})$ \\
\hline 14 & SD-29 & & from \#I-5 Ore Vein & $362(\mathrm{E})$ & $\mathrm{n} / \mathrm{a}$ & $(332-396)(\mathrm{E})$ \\
\hline 15 & SD-41 & & from \#I-1 Ore Vein & $375(\mathrm{E})$ & 325 & \\
\hline 16 & SD-52 & & from a dolomite vein at schist-marble contact & $234(\mathrm{~L})$ & 131 & \\
\hline 17 & SD-55 & & from \#I-10 Ore Vein & $\mathrm{n} / \mathrm{a}$ & $\mathrm{n} / \mathrm{a}$ & \\
\hline 18 & SD-34 & tetradymite & from \#I-4 Ore Vein & 231 & 78 & \\
\hline 19 & SD-36 & & from \#I-5 Ore Vein & 255 & $\mathrm{n} / \mathrm{a}$ & \\
\hline 20 & SD-40 & & from \#I-1 Ore Vein & 222 & $\mathrm{n} / \mathrm{a}$ & 229 \\
\hline 21 & SD-46 & & from \#I-2 Ore Vein & 223 & $\mathrm{n} / \mathrm{a}$ & $(186-255)$ \\
\hline 22 & SD-58 & & from \#I-10 Ore Vein & 248 & $\mathrm{n} / \mathrm{a}$ & \\
\hline 23 & SD-59 & & from \#I-10 Ore Vein & 241 & $\mathrm{n} / \mathrm{a}$ & \\
\hline 24 & SD-61 & & from \#I-10 Ore Vein & 186 & $\mathrm{n} / \mathrm{a}$ & \\
\hline 25 & SL-23 & chalcocite & from (No Suggestions) Cu-Au showing nearby & $112,181,313$ & $\mathrm{n} / \mathrm{a}$ & $\mathrm{n} / \mathrm{a}$ \\
\hline 26 & SD12-1 & dolomite & from a dolomite vein between \# II \& III Ore Zones & $298(\mathrm{E})$ & $\mathrm{n} / \mathrm{a}$ & \\
\hline 27 & SD-23 & & from \#I-4 Ore Vein & $317(\mathrm{E})$ & $\mathrm{n} / \mathrm{a}$ & \\
\hline 28 & SD-29 & & from \#I-5 Ore Vein & $301,344(\mathrm{E})$ & $\mathrm{n} / \mathrm{a}$ & \\
\hline 29 & SD-36 & & from \#I-5 Ore Vein & $308(\mathrm{E})$ & $\mathrm{n} / \mathrm{a}$ & $317(\mathrm{E})$ \\
\hline 30 & SD-40 & & from \#I-1 Ore Vein & $334(\mathrm{E})$ & $\mathrm{n} / \mathrm{a}$ & $(250-452)$ \\
\hline 31 & SD-46 & & from \#I-2 Ore Vein & $317,375(\mathrm{E})$ & $\mathrm{n} / \mathrm{a}$ & \\
\hline 32 & SD-59 & & from \#I-10 Ore Vein & $334,406(\mathrm{E})$ & $\mathrm{n} / \mathrm{a}$ & \\
\hline 33 & SD65-1 & & from \#I-8 Ore Vein & $452,250(\mathrm{E})$ & 169,59 & \\
\hline 34 & SD-62 & & from \#I-9 Ore Vein & $155(\mathrm{E})$ & $\mathrm{n} / \mathrm{a}$ & $159.5(\mathrm{E})$ \\
\hline 35 & SD-71 & & Pyr vein within \# I-1 Ore Vein & $164(\mathrm{E})$ & $\mathrm{n} / \mathrm{a}$ & $(155-164)$ \\
\hline 36 & SD-70 & & from a dolomite vein within \#I Ore Zone & $150(\mathrm{~L})$ & $\mathrm{n} / \mathrm{a}$ & \\
\hline 37 & SD-52 & & from a dolomite vein at schist-marble contact & $298(\mathrm{~L})$ & $\mathrm{n} / \mathrm{a}$ & $241(\mathrm{~L})$ \\
\hline 38 & SD-44 & & from \#I-3 Ore Vein & $267(\mathrm{~L})$ & 320 & $(150-298)$ \\
\hline 39 & SL-09 & & from a dolomite vein outside the mine & $250(\mathrm{~L})$ & $\mathrm{n} / \mathrm{a}$ & \\
\hline 40 & SD-49 & calcite & from the banded marble within the mine & 327 & $\mathrm{n} / \mathrm{a}$ & 287.5 \\
\hline 41 & SD-69 & & from coarse grained marble within the mine & 248 & $\mathrm{n} / \mathrm{a}$ & $(248-327)$ \\
\hline 42 & SD-10 & chalcopyrite & from a quartz vein between \# II \& III Ore Zones & 346 & $\mathrm{n} / \mathrm{a}$ & \\
\hline 43 & SD-15 & & from the Pyr vein of \# III Ore Zone & 298 & $\mathrm{n} / \mathrm{a}$ & 336 \\
\hline 44 & SD-16 & & from the \#III-2 Pyr vein & 363 & $\mathrm{n} / \mathrm{a}$ & $(298-363)$ \\
\hline 45 & SD-71 & & from the Pyr vein within \# I Ore Zone & $\mathrm{n} / \mathrm{a}$ & 435 & \\
\hline 46 & SD-11 & quartz & from a quartz vein between \# II \& III Ore Zones & 174,399 & $\mathrm{n} / \mathrm{a}$ & 117 \\
\hline 47 & SD-26 & & from \#I-4 Ore Vein & 100 & $\mathrm{n} / \mathrm{a}$ & $(78-174)$ \\
\hline 48 & SD-27 & & from \#I-5 Ore Vein & 78 & $\mathrm{n} / \mathrm{a}$ & \\
\hline 49 & SL-11 & tourmaline & from a tourmaline-quartz vein outside the mine & 94 & $\mathrm{n} / \mathrm{a}$ & 94 \\
\hline
\end{tabular}


Table 2a : Characteristics of fluid inclusions in the minerals from the deposit.

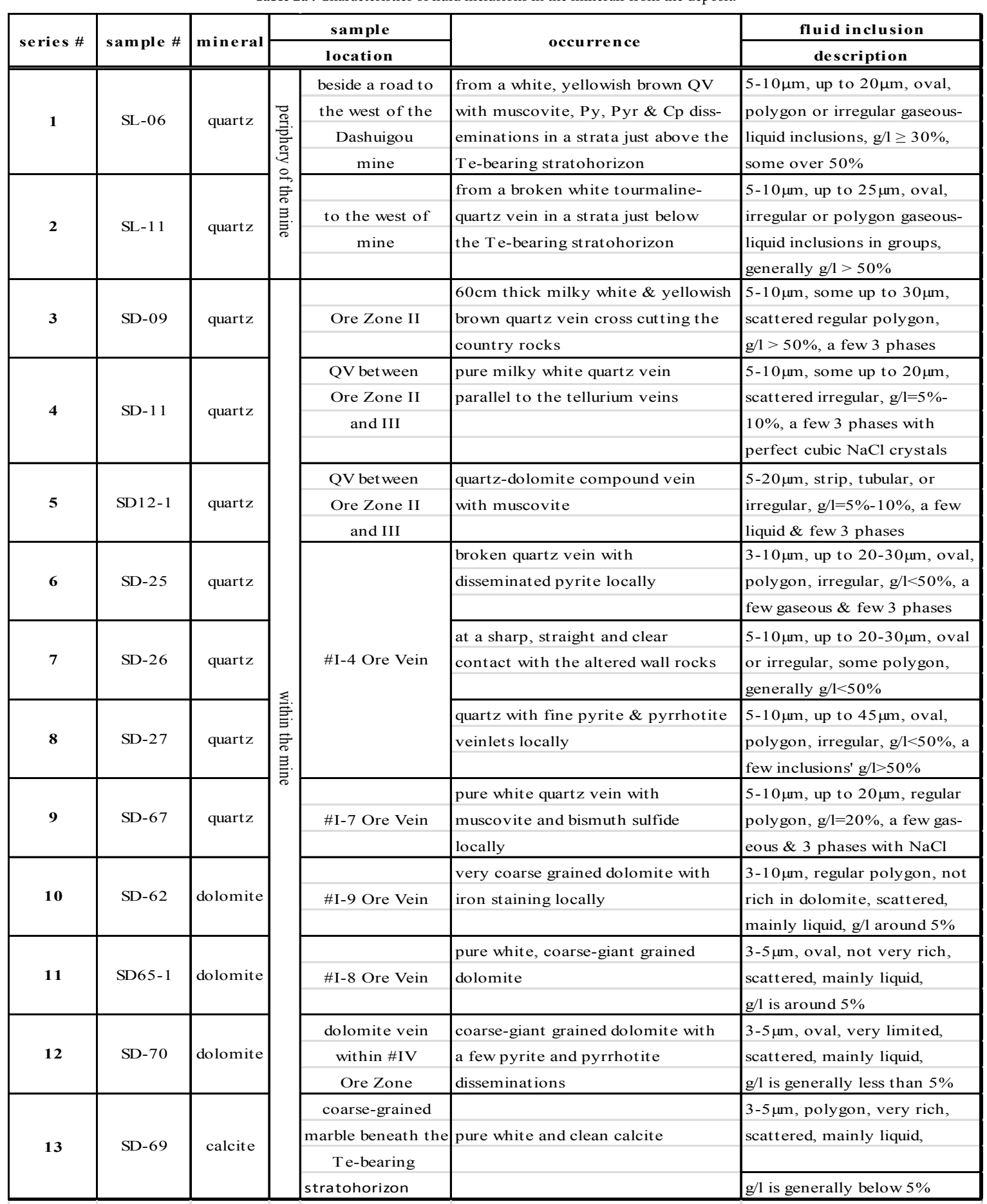

Notes: QV-quartz vein, Py-pyrite, Pyr-pyrrhotite, Cp-chalcopyrite, g/l-gas/liquid ratio within an inclusion.

To be cont'd

Fluid inclusions in both dolomite and calcite are usually oval and/ or polygon in shape, while those in quartz are either oval, polygon, irregular, strip and/or tubular. A few perfect cubic $\mathrm{NaCl}$ crystals could be seen in several of the fluid inclusions in quartz (Figure 9).

\section{Chemical Compositions}

Chemical compositions of the fluid inclusions of part of the gangue and ore minerals are listed in Table 3. It can be seen from the table that cations in the fluid inclusions include $\mathrm{Na}^{+}, \mathrm{K}^{+}, \mathrm{Ca}^{2+}$ and $\mathrm{Mg}^{2+}$, while anions include $\mathrm{SO}_{4}^{2-}, \mathrm{Cl}^{-}$and $\mathrm{F}^{-}$, and the major gaseous compositions include $\mathrm{H}_{2} \mathrm{O}$ and $\mathrm{CO}_{2}$, with smaller $\mathrm{CH}_{4}, \mathrm{H}_{2}, \mathrm{~N}_{2}, \mathrm{CO}$ and $\mathrm{C}_{2} \mathrm{H}_{6} . \mathrm{Na}^{+} / \mathrm{K}^{+}$ ratios of the fluid inclusions of the region's minerals are either above or below 1.0, meaning that compositions of the hydrothermal solutions are not homogeneous. $\mathrm{Ca}^{2+} / \mathrm{Mg}^{2+}$ ratios of the fluid inclusions are 
Table 2b : Characteristics of fluid inclusions in the minerals from the deposit (cont'd)

\begin{tabular}{|c|c|c|c|c|c|c|c|}
\hline \multirow{2}{*}{ series \# } & 3 pIHT T$^{1}\left({ }^{\circ} \mathrm{C}\right)$ & NCIVT $^{2}$ & $\mathbf{D T}^{3}$ & $\mathbf{H T}^{4}$ & salinity (wt.\%) & pressure $^{5}$ & depth $^{6}$ \\
\hline & $\mathrm{LCO}_{2}+\mathrm{VCO}_{2} \rightarrow \mathrm{LCO}_{2}$ & ${ }^{\circ} \mathrm{C}$ & ${ }^{\circ} \mathrm{C}$ & ${ }^{\circ} \mathrm{C}$ & $\mathrm{NaCl}$ & Kbar & $\mathbf{k m}$ \\
\hline \multirow{2}{*}{1} & \multirow{2}{*}{9.0} & \multirow{2}{*}{$\mathrm{n} / \mathrm{a}$} & 207.0 & $291.3-419.4$ & $\underline{10.4-17.6}$ & \multirow{2}{*}{1.950} & \multirow{2}{*}{$7.80-6.50$} \\
\hline & & & pyrite in quartz vein & 369.4 & 13.8 & & \\
\hline \multirow{2}{*}{2} & \multirow{2}{*}{21.3} & \multirow{2}{*}{$\mathrm{n} / \mathrm{a}$} & 94.0 & $\underline{337.0-340.1}$ & $\underline{13.5-16.8}$ & \multirow{2}{*}{1.340} & \multirow{2}{*}{$5.36-4.47$} \\
\hline & & & tourmaline in QV & 339.0 & 15.2 & & \\
\hline \multirow{2}{*}{3} & \multirow{2}{*}{21.0} & \multirow{2}{*}{$\mathrm{n} / \mathrm{a}$} & \multirow{2}{*}{$\mathrm{n} / \mathrm{a}$} & $144.0-203.0$ & $15.1-18.4$ & \multirow{2}{*}{0.515} & \multirow{2}{*}{$2.06-1.72$} \\
\hline & & & & 180.0 & 16.2 & & \\
\hline \multirow{2}{*}{4} & \multirow{2}{*}{25.4} & \multirow{2}{*}{$219.9-300.8$} & \multirow{2}{*}{174.4} & $367.0-425.9$ & $\underline{34.0-38.5}$ & \multirow{2}{*}{1.540} & \multirow{2}{*}{$6.16-5.13$} \\
\hline & & & & 397.0 & 36.2 & & \\
\hline \multirow{2}{*}{5} & \multirow{2}{*}{15.0} & $(188.0-234.6)^{*}$ & \multirow{2}{*}{$\mathrm{n} / \mathrm{a}$} & $\underline{403.8-426.8}$ & $\underline{18.4-34.6}$ & \multirow[b]{2}{*}{1.800} & \multirow[b]{2}{*}{$7.20-6.00$} \\
\hline & & 219.3 & & 415.3 & 26.6 & & \\
\hline \multirow{2}{*}{6} & \multirow{2}{*}{13.4} & \multirow{2}{*}{$\mathrm{n} / \mathrm{a}$} & \multirow{2}{*}{$\mathrm{n} / \mathrm{a}$} & $209.8-234.0$ & $15.2-21.3$ & \multirow{2}{*}{1.020} & \\
\hline & & & & 225.0 & 18.7 & & $4.00-5.40$ \\
\hline 7 & 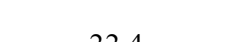 & $x_{0}$ & $100 \Omega$ & $\underline{173.0-251.0}$ & $\underline{15.6-21.3}$ & $080 ?$ & 25200 \\
\hline 1 & 22.4 & $n / \mathrm{d}$ & 100.0 & 216.3 & 18.0 & 0.002 & $3.53-2.94$ \\
\hline 0 & 100 & $\log ^{2}+2$ & 780 & $\underline{148.0-252.3}$ & $\underline{12.0-18.6}$ & 0617 & 5021 \\
\hline $\mathbf{0}$ & 19.0 & n/d & 10.0 & 202.3 & 14.9 & 0.047 & $2.59-2.10$ \\
\hline & & $\underline{195.6-330.0}$ & & $195.5-522.4$ & $15.0-40.5$ & & \\
\hline (3) & 21.3 & 258.8 & n/a & 337.7 & 27.4 & 0.950 & $3.02-3.19$ \\
\hline 10 & $\mathrm{n} / \mathrm{a}$ & $\mathrm{n} / \mathrm{a}$ & 155.0 & 165.0 & $\mathrm{n} / \mathrm{a}$ & $\mathrm{n} / \mathrm{a}$ & $\mathrm{n} / \mathrm{a}$ \\
\hline 11 & $\mathrm{n} / \mathrm{a}$ & $\mathrm{n} / \mathrm{a}$ & $169,250,452$ & 2380 & $\mathrm{n} / \mathrm{a}$ & $\mathrm{n} / \mathrm{a}$ & $\mathrm{n} / \mathrm{a}$ \\
\hline 12 & $\mathrm{n} / \mathrm{a}$ & $\mathrm{n} / \mathrm{a}$ & 150.0 & 1347 & $\mathrm{n} / \mathrm{a}$ & $\mathrm{n} / \mathrm{a}$ & $\mathrm{n} / \mathrm{a}$ \\
\hline $12+3$ & the & at & 2400 & $\underline{147.4-213.9}$ & $\underline{0.5-5.6}$ & $x^{2}+2$ & the \\
\hline & & & & 180.7 & 3.1 & & \\
\hline
\end{tabular}

Notes: 1 - 3-phase inclusion homogenization temperature, 2 - $\mathrm{NaCl}$ crystal inclusion vanished temperature, 3 - decrepitation temperature (see Table 1) , 4 - homogenization temperature, 5 - calculated on isoline analysis, 6 - calculated at a pressure rate of $\left.(0.25-0.30) \times 10^{8} \mathrm{~Pa} / \mathrm{km}\left(1 \mathrm{bar}=1 \times 10^{5} \mathrm{~Pa}\right),(188.0-234.6) / 219.3\right)^{*}-($ min value - max value $) /$ average value.

all above 1.0, meaning that the metallogenic solutions are rich in $\mathrm{Ca}^{2+}$ but poor in $\mathrm{Mg}^{2+}$. Both $\mathrm{SO}_{4}^{2-} / \mathrm{Cl}^{-}$and $\mathrm{Cl}^{-} / \mathrm{F}^{-}$ratios are over 1.0, meaning that the metallogenic solutions are richest in $\mathrm{SO}_{4}^{2-}$, moderate in $\mathrm{Cl}^{\text {, but }}$ poor in $\mathrm{F}$. Most of the samples had $\mathrm{H}_{2} \mathrm{O} / \mathrm{CO}_{2}$ ratios of over 1.0, meaning the solutions are richer in $\mathrm{H}_{2} \mathrm{O}$ than in $\mathrm{CO}_{2}$. $\left(\mathrm{CO}_{2}\right.$ $\left.+\mathrm{H}_{2}+\mathrm{CH}_{4}\right) / \mathrm{N}_{2}$ values of all samples are over 1.0, showing that the hydrothermal solutions are rich in $\mathrm{CO}_{2}, \mathrm{H}_{2}$ and $\mathrm{CH}_{4}$.

\section{Discussion}

Previous research on the ore-forming fluid of the Dashuigou tellurium deposit is roughly divided into the magma hydrothermal theory $[4-6,10,11,26,28,29]$, the metamorphic hydrothermal theory $[30,31]$, and the mixed hydrothermal theory [5,9,30] obtained the study of gas-liquid inclusions and found that the ore-forming temperature of the Dashuigou tellurium deposit varied between 350 and $120^{\circ} \mathrm{C}$. The salinity is $7.2 \mathrm{wt} \% \sim 35 \mathrm{wt} \% \mathrm{NaCl}$, of which the salinity value in the early and late quartz veins can be as high as 20 wt $\%$ to $35 \mathrm{wt} \% \mathrm{NaCl}$, the oxygen fugacity is $f_{\mathrm{O} 2}=-42.26 \sim-45.49$, and the ore-forming hydrothermal fluid is weakly acidic and neutral $(\mathrm{pH}=6.32 \sim 6.29)$. The $\mathrm{CO}_{2} / \mathrm{H}_{2} \mathrm{O}$ ratio in the quartz is $0.137 \sim 0.208$, and the $\mathrm{CH}_{4}$ content is $12.61 \sim 24.85 \mathrm{ml} / 100 \mathrm{~g}$. Based on uniform temprature measurement of the gas-liquid inclusions in the deposit's dolomite and quartz, Li [29] and Cao [10-11] concluded that the uniform temperature of each mineralization stage is roughly similar: $221 \sim 259^{\circ} \mathrm{C}$, average $239^{\circ} \mathrm{C}$ for Stage I; $215 \sim 256^{\circ} \mathrm{C}$, average $235^{\circ} \mathrm{C}$ for Stage II; $192 \sim 243^{\circ} \mathrm{C}$, average $224^{\circ} \mathrm{C}$ for Stage III. The corresponding metallogenic pressure is $823.684 \times 10^{5} \mathrm{~Pa} \sim 965.409 \times 10^{5} \mathrm{~Pa}$, with an average of $884.156 \times 10^{5} \mathrm{~Pa}$. Both $\mathrm{CO}_{2}$ and $\mathrm{H}_{2} \mathrm{O}-\mathrm{CO}_{2}$ inclusions are abundant, reflecting that mineralization occurs under relatively closed conditions. The metallogenic depth estimated by the static rock pressure model is $3,339 \mathrm{~m}$, which is equivalent to the thickness of the measured overlying strata $(3650 \mathrm{~m})$. Since the characteristics of inclusion types in each mineralization stage are not substantially different, they are considered to have similar metallogenic depths. 


\begin{tabular}{|c|c|c|c|c|c|c|c|c|c|c|}
\hline \multirow{2}{*}{ series \# } & \multirow{2}{*}{ sample \# } & \multirow{2}{*}{ mineral } & \multirow{2}{*}{$\begin{array}{l}\text { sample } \\
\text { location } \\
\end{array}$} & \multicolumn{7}{|c|}{ gaseous composition $(\mu \mathrm{g} / \mathrm{g})$} \\
\hline & & & & $\mathrm{H}_{2} \mathrm{O}$ & $\mathrm{CO}_{2}$ & $\mathbf{H}_{2}$ & $\mathrm{CH}_{4}$ & $\mathbf{N}_{2}$ & $\mathrm{CO}$ & $\mathrm{C}_{2} \mathrm{H}_{6}$ \\
\hline 1 & SD-11 & quartz & QV between \#II \& III Ore Veins & 246.0 & 200.0 & 0.120 & 1.600 & 5.500 & 0.001 & 0.001 \\
\hline 2 & $\mathrm{SD}-26$ & quartz & from \#I-4 Ore Vein & 366.0 & 236.0 & 0.105 & 11.700 & 2.000 & 0.001 & 0.001 \\
\hline 3 & SD-27 & quartz & from \#I-4 Ore Vein & 150.0 & 160.0 & 0.018 & 10.000 & 1.800 & 0.001 & 0.001 \\
\hline 4 & SL-1 1 & tourmaline & from a QV outside the mine & 117.0 & 342.0 & 0.150 & 4.000 & 1.300 & 0.001 & 0.001 \\
\hline 5 & SL-09 & dolomite & from a DV outside the mine & 210.0 & 164.0 & 2.640 & 2.600 & 0.800 & 0.001 & 0.001 \\
\hline 6 & SD12-1 & dolomite & a DV between \#II \& III Ore Veins & 334.0 & 640.0 & 4.750 & 1.600 & 1.800 & 0.001 & 0.001 \\
\hline 7 & $\mathrm{SD}-40$ & dolomite & from \#I-1 Ore Vein & 150.0 & 1136.0 & 5.340 & 5.200 & 3.250 & 0.001 & 0.001 \\
\hline 8 & $\mathrm{SD}-44$ & dolomite & from \#I-3 Ore Vein & 700.0 & 828.0 & 22.200 & 2.000 & 18.000 & 0.001 & 0.001 \\
\hline 9 & SD-46 & dolomite & from $\# \mathrm{I}-2$ Ore Vein & 282.0 & 3500.0 & 3.100 & 14.000 & 5.000 & 0.001 & 0.001 \\
\hline 10 & SD-59 & dolomite & from \#I-10 Ore Vein & 162.0 & 828.0 & 10.600 & 3.400 & 4.000 & 0.001 & 0.001 \\
\hline 11 & SD-62 & dolomite & from \#I-9 Ore Vein & 282.0 & 904.0 & 4.480 & 2.000 & 5.750 & 0.001 & 0.001 \\
\hline 12 & SD65-1 & dolomite & from \#I-8 Ore Vein & 282.0 & 945.0 & 4.000 & 4.440 & 10.500 & 0.001 & 0.001 \\
\hline 13 & SD-71 & dolomite & from $\mathrm{Pr}-\mathrm{D}$ vein of \#IV ore zone & 210.0 & 1250.0 & 4.990 & 12.400 & 4.000 & 0.001 & 0.001 \\
\hline 14 & SD-49 & calcite & from banded marble at \#4 adit portal & 33.0 & 29.0 & 2.110 & 3.400 & 1.300 & 0.001 & 0.001 \\
\hline 15 & SD-69 & calcite & from the Triassic marble of the mine & 138.0 & 84.0 & 2.700 & 3.100 & 1.000 & 0.001 & 0.001 \\
\hline 16 & SD-10 & pyrrhotite & from a Pyr vein between \#II \& III Ore Zones & 812.0 & 224.0 & 0.075 & 0.001 & 2.250 & 0.001 & 0.001 \\
\hline 17 & SD-15 & pyrrhotite & from \#III-1 Pyr Vein & 925.0 & 232.0 & 0.090 & 0.001 & 1.600 & 0.001 & 0.001 \\
\hline 18 & SD-55 & pyrrhotite & from $\# \mathrm{I}-10$ Ore Vein & 756.0 & 132.0 & 0.080 & 0.001 & 1.300 & 0.001 & 0.001 \\
\hline 19 & SD-65 & pyrrhotite & from \#I-8 Ore Vein & 850.0 & 284.0 & 0.220 & 0.001 & 1.600 & 0.001 & 0.001 \\
\hline 20 & $\mathrm{SD}-41$ & pyrite & from \#I-1 Ore Vein & 15.0 & 10.0 & 0.001 & 0.001 & 1.300 & 0.001 & 0.001 \\
\hline 21 & SD-17 & pyrite & from \#III-2 Pyr Vein & 21.0 & 18.0 & 0.001 & 0.001 & 1.600 & 0.001 & 0.001 \\
\hline 22 & SD-23 & pyrite & from \#I-4 Ore Vein & 21.0 & 12.0 & 0.001 & 0.001 & 0.800 & 0.001 & 0.001 \\
\hline 23 & SD-29 & pyrite & from $\# \mathrm{I}-5$ Ore Vein & 27.0 & 20.0 & 0.001 & 0.001 & 1.000 & 0.001 & 0.001 \\
\hline 24 & SD-55 & pyrite & from \#I-10 Ore Vein & 21.0 & 18.0 & 0.001 & 0.001 & 0.000 & 0.001 & 0.001 \\
\hline 25 & SD-15 & chalcopyrite & from \#III-1 Pyr Vein & 344.0 & 58.5 & 0.018 & 0.001 & 1.000 & 0.001 & 0.001 \\
\hline
\end{tabular}

Note: DV - dolomite vein, Pyr - D-pyrrhotite-dolomite.

to be continued

According to the ore-forming pressure and salinity, the temperature correction value was found to be about $80^{\circ} \mathrm{C}$, so the metallogenic temperatures of stages I, II, and III were $319^{\circ} \mathrm{C}, 315^{\circ} \mathrm{C}$, and $304^{\circ} \mathrm{C}$, respectively. The salinity of ores from this deposit varies widely, with $\mathrm{NaCl}$ content ranging from $7.17 \%$ to $33.27 \%$. Among them, the rock salt gas-liquid water inclusions have the highest salinity, while the gasliquid water inclusions and liquid-liquid $\mathrm{H}_{2} \mathrm{O}-\mathrm{CO}_{2}$ inclusions have lower salinity and are basically the same. The salinity of fluids in each mineralization stage is roughly similar, where the $\mathrm{NaCl}$ content in stage I is $16.5 \% \sim 30.83 \%$, with an average of $21.21 \%$; stage II is $17.66 \%$ $\sim 33.27 \%$, with an average of $25.77 \%$; stage III is $7.17 \% \sim 32.34 \%$, with an average of $17.55 \%$. The gas phase composition is mainly $\mathrm{H}_{2} \mathrm{O}$, followed by $\mathrm{CO}_{2}$, and containing a small amount of $\mathrm{H}_{2}, \mathrm{CO}$ and $\mathrm{CH}_{4}$. According to observation under a microscope, the fluid inclusions in the minerals from this deposit are mainly $\mathrm{H}_{2} \mathrm{O}-\mathrm{CO}_{2}$ and $\mathrm{CO}_{2}$. The $f_{\mathrm{O} 2}$ of the mineralization fluid is: stage I $10.0 \times 10^{5} \sim 34.0 \times 10^{5} \mathrm{~Pa}$, stage III $10.0 \times 10^{5} \sim 34.8 \times 10^{5} \mathrm{~Pa}$, stage III $10.0 \times 10^{5} \sim 35.6 \times 10^{5} \mathrm{~Pa}$. The $\mathrm{pH}$ value of the hydrothermal solution during the tellurium mineralization stage is $5.91 \sim 5.87$. Through study of gas-liquid inclusions from the same deposit, Chen [28] concluded that the inclusions are rich in $\mathrm{CO}_{2}$, $\mathrm{CO}_{2}-\mathrm{H}_{2} \mathrm{O}$ (low salinity fluid), and $\mathrm{CO}_{2}-\mathrm{H}_{2} \mathrm{O}-\mathrm{NaCl}$ (high salinity fluid); namely, three systems of fluid inclusions exist in the deposit, of which tellurium mineralization is related to the first two systems. Most of the inclusions leak and/or burst before being homogenized. The metallogenic temperature of the pyrrhotite stage is around $500^{\circ} \mathrm{C}$ and that of the telluride stage is $400^{\circ} \mathrm{C}$. The fluid density changes between $1.04 \sim 0.76 \mathrm{~g} / \mathrm{cm}^{3}$, and the metallogenic pressures are respectively $450 \sim 500 \mathrm{MPa}$ and $240 \sim 300 \mathrm{MPa}$. Mineralization occurs under high temperature and high pressure. The results of this paper are as follows: fluid inclusion homogenization temperatures vary greatly (Table 2): those of quartz formed in pre-tellurium mineralization and collected outside the deposit are between 339.0 and $369.4^{\circ} \mathrm{C}$. These samples include series \#1, 2, 4 and 5 in Table 2. Other quartz samples in Table 2 are associated with telluride veins and their fluid inclusion homogenization temperatures should be at typical values when tellurium ore bodies emplaced, or between $180.0-250.0^{\circ} \mathrm{C}$. This range includes part of the decrepitation temperatures of those minerals formed during the tellurium epoch mentioned earlier in this paper. The salinity of fluid inclusions within the whole metallogenic epochs varies between $13.8 \%-36.2 \%$, which falls into a medium-high salinity range. That of minerals formed during the tellurium epoch, for instance three quartz samples associated with tellurides and collected from \#I-4 Ore Vein in Table 2, is between 14.9\%-18.7\%, well within the medium salinity range. The formation pressures of mineral fluid inclusions 
Table 3b : Chemical compositions of the fluid inclusions in the minerals (cont'd).

\begin{tabular}{|c|c|c|c|c|c|c|c|c|c|c|}
\hline \multirow{2}{*}{ series \# } & \multicolumn{10}{|c|}{ liquid composition $(\mu \mathrm{g} / \mathrm{g})$} \\
\hline & $\mathrm{Na}^{+}$ & $\mathbf{K}^{+}$ & $\mathrm{Ca}^{2+}$ & $\mathbf{M g}^{2+}$ & $\mathbf{C l}$ & $\mathbf{F}^{-}$ & $\mathrm{SO}_{4}{ }^{2-}$ & $\mathrm{NO}_{3}^{-}$ & $\mathbf{B r}^{-}$ & $\mathrm{PO}_{4}{ }^{3}$ \\
\hline 1 & 22.90 & 8.20 & 1.8 & 1.14 & 8.01 & 1.19 & 43.8 & 0.00 & 0.00 & 0.00 \\
\hline 2 & 15.10 & 6.56 & 1.5 & 0.98 & 4.68 & 1.10 & 39.5 & 0.00 & 0.00 & 0.00 \\
\hline 3 & 11.40 & 5.45 & 1.2 & 0.33 & 2.21 & 0.91 & 49.5 & 0.00 & 0.00 & 0.00 \\
\hline 4 & 7.81 & 4.92 & 1.8 & 2.45 & 1.51 & 1.41 & 32.6 & 0.00 & 0.00 & 0.00 \\
\hline 5 & 2.92 & 2.18 & $\mathrm{n} / \mathrm{a}$ & $\mathrm{n} / \mathrm{a}$ & 4.02 & 0.40 & 50.7 & 0.00 & 0.00 & 0.00 \\
\hline 6 & 13.30 & 3.27 & $\mathrm{n} / \mathrm{a}$ & $\mathrm{n} / \mathrm{a}$ & 26.30 & 0.95 & 70.4 & 0.00 & 0.00 & 0.00 \\
\hline 7 & 4.88 & 2.46 & $\mathrm{n} / \mathrm{a}$ & $\mathrm{n} / \mathrm{a}$ & 11.40 & 1.60 & 100.0 & 0.00 & 0.00 & 0.00 \\
\hline 8 & 4.22 & 4.36 & $\mathrm{n} / \mathrm{a}$ & $\mathrm{n} / \mathrm{a}$ & 8.83 & 1.80 & 187.0 & 0.00 & 0.00 & 0.00 \\
\hline 9 & 2.60 & 0.001 & $\mathrm{n} / \mathrm{a}$ & $\mathrm{n} / \mathrm{a}$ & 25.50 & 13.80 & 5490.0 & 0.00 & 0.00 & 0.00 \\
\hline 10 & 19.50 & 32.80 & $\mathrm{n} / \mathrm{a}$ & $\mathrm{n} / \mathrm{a}$ & 4.58 & 3.78 & 1934.0 & 0.00 & 0.00 & 0.00 \\
\hline 11 & \begin{tabular}{|l|}
10.10 \\
\end{tabular} & 7.08 & $\mathrm{n} / \mathrm{a}$ & $\mathrm{n} / \mathrm{a}$ & 11.30 & 0.87 & 471.0 & 0.00 & 0.00 & 0.00 \\
\hline 12 & 8.30 & 2.46 & $\mathrm{n} / \mathrm{a}$ & $\mathrm{n} / \mathrm{a}$ & 1.82 & 0.44 & 225.0 & 0.00 & 0.00 & 0.00 \\
\hline 13 & 6.82 & 3.27 & $\mathrm{n} / \mathrm{a}$ & $\mathrm{n} / \mathrm{a}$ & 6.69 & 1.60 & 1313.0 & 0.00 & 0.00 & 0.00 \\
\hline 14 & 2.44 & 2.46 & $\mathrm{n} / \mathrm{a}$ & $\mathrm{n} / \mathrm{a}$ & 4.84 & 0.62 & 147.0 & 0.00 & 0.00 & 0.00 \\
\hline 15 & 1.95 & 3.28 & $\mathrm{n} / \mathrm{a}$ & $\mathrm{n} / \mathrm{a}$ & 2.34 & 0.97 & 49.7 & 0.00 & 0.00 & 0.00 \\
\hline 16 & 63.40 & 82.00 & 1000.0 & 909.0 & 1.40 & 0.97 & $\mathrm{n} / \mathrm{a}$ & 0.00 & 0.00 & 0.00 \\
\hline 17 & 29.30 & 24.60 & 1750.0 & 2545.0 & 2.08 & 1.98 & $\mathrm{n} / \mathrm{a}$ & 0.00 & 0.00 & 0.00 \\
\hline 18 & \begin{tabular}{|l|}
29.30 \\
\end{tabular} & 24.60 & 750.0 & 364.0 & 8.50 & 1.54 & $\mathrm{n} / \mathrm{a}$ & 0.00 & 0.00 & 0.00 \\
\hline 19 & \begin{tabular}{|l|}
29.30 \\
\end{tabular} & 65.80 & 7500.0 & 273.0 & 1.98 & 1.76 & $\mathrm{n} / \mathrm{a}$ & 0.00 & 0.00 & 0.00 \\
\hline 20 & 12.20 & 16.40 & 1250.0 & 909.0 & 3.60 & 1.85 & $\mathrm{n} / \mathrm{a}$ & 0.00 & 0.00 & 0.00 \\
\hline 21 & 19.50 & 16.40 & 500.0 & 364.0 & 3.10 & 1.62 & $\mathrm{n} / \mathrm{a}$ & 0.00 & 0.00 & 0.00 \\
\hline 22 & 22.00 & 8.20 & 1500.0 & 182.0 & 1.44 & 1.85 & $\mathrm{n} / \mathrm{a}$ & 0.00 & 0.00 & 0.00 \\
\hline 23 & 14.60 & 16.40 & 1250.0 & 273.0 & 5.70 & 4.62 & $\mathrm{n} / \mathrm{a}$ & 0.00 & 0.00 & 0.00 \\
\hline 24 & 34.20 & 49.20 & 500.0 & 454.0 & 3.80 & 2.23 & $\mathrm{n} / \mathrm{a}$ & 0.00 & 0.00 & 0.00 \\
\hline 25 & 39.00 & 32.80 & 1750.0 & 1091.0 & 1.77 & 1.32 & $\mathrm{n} / \mathrm{a}$ & 0.00 & 0.00 & 0.00 \\
\hline
\end{tabular}

to be continued

Table 3c: Chemical compositions of the fluid inclusions in the minerals (cont'd).

\begin{tabular}{|c|c|c|c|c|c|c|}
\hline series \# & $\mathrm{Na}^{+} / \mathbf{K}^{+}$ & $\mathrm{Ca}^{2+} / \mathrm{Mg}^{2+}$ & $\mathrm{Cl}^{-} / \mathrm{F}^{-}$ & $\mathrm{SO}_{4}{ }^{2-} / \mathrm{Cl}^{-}$ & $\mathrm{H}_{2} \mathrm{O} / \mathrm{CO}_{2}$ & $\left(\mathrm{CO}_{2}+\mathrm{H}_{2}+\mathrm{CH}_{4}\right) / \mathrm{N}_{2}$ \\
\hline 1 & 2.79 & 1.58 & 6.73 & 5.47 & 1.230 & 36.680 \\
\hline 2 & 2.30 & 1.53 & 4.25 & 8.44 & 1.550 & 123.900 \\
\hline 3 & 2.09 & 3.64 & 2.42 & 22.40 & 0.940 & 94.450 \\
\hline 4 & 1.59 & 0.73 & 1.07 & 21.60 & 0.340 & 266.270 \\
\hline 5 & 1.34 & $\mathrm{n} / \mathrm{a}$ & 10.18 & 12.61 & 1.280 & 211.550 \\
\hline 6 & 4.07 & $\mathrm{n} / \mathrm{a}$ & 27.83 & 2.67 & 0.520 & 359.080 \\
\hline 7 & 1.98 & $\mathrm{n} / \mathrm{a}$ & 7.13 & 8.77 & 0.130 & 365.910 \\
\hline 8 & 0.95 & $\mathrm{n} / \mathrm{a}$ & 4.91 & 21.18 & 0.850 & 46.410 \\
\hline 9 & 2600.0 & $\mathrm{n} / \mathrm{a}$ & 1.85 & 215.29 & 0.080 & 707.240 \\
\hline 10 & 0.59 & $\mathrm{n} / \mathrm{a}$ & 1.21 & 422.27 & 0.200 & 208.630 \\
\hline 11 & 1.43 & $\mathrm{n} / \mathrm{a}$ & 12.99 & 41.68 & 0.310 & 159.410 \\
\hline 12 & 3.37 & $\mathrm{n} / \mathrm{a}$ & 4.14 & 123.63 & 0.300 & 90.850 \\
\hline 13 & 2.09 & $\mathrm{n} / \mathrm{a}$ & 4.18 & 196.26 & 0.170 & 316.850 \\
\hline 14 & 0.99 & $\mathrm{n} / \mathrm{a}$ & 7.86 & 30.37 & 1.140 & 26.550 \\
\hline 15 & 0.59 & $\mathrm{n} / \mathrm{a}$ & 2.42 & 21.24 & 1.640 & 89.800 \\
\hline 16 & 0.77 & 1.10 & 1.45 & $\mathrm{n} / \mathrm{a}$ & 3.630 & 99.590 \\
\hline 17 & 1.19 & 0.69 & 1.05 & $\mathrm{n} / \mathrm{a}$ & 3.990 & 145.060 \\
\hline 18 & 1.19 & 2.06 & 5.52 & $\mathrm{n} / \mathrm{a}$ & 5.730 & 101.600 \\
\hline 19 & 0.45 & 27.47 & 1.13 & $\mathrm{n} / \mathrm{a}$ & 2.990 & 177.640 \\
\hline 20 & 0.74 & 1.38 & 1.95 & $\mathrm{n} / \mathrm{a}$ & 1.500 & 7.690 \\
\hline 21 & 1.19 & 1.37 & 1.91 & $\mathrm{n} / \mathrm{a}$ & 1.170 & 11.250 \\
\hline 22 & 2.68 & 8.24 & 1.32 & $\mathrm{n} / \mathrm{a}$ & 1.750 & 15.000 \\
\hline 23 & 0.89 & 4.58 & 1.23 & $\mathrm{n} / \mathrm{a}$ & 1.350 & 20.002 \\
\hline 24 & 0.70 & 1.10 & 1.70 & $\mathrm{n} / \mathrm{a}$ & 1.170 & $\infty+$ \\
\hline 25 & 1.19 & 1.60 & 1.34 & $\mathrm{n} / \mathrm{a}$ & 5.880 & 58.519 \\
\hline
\end{tabular}




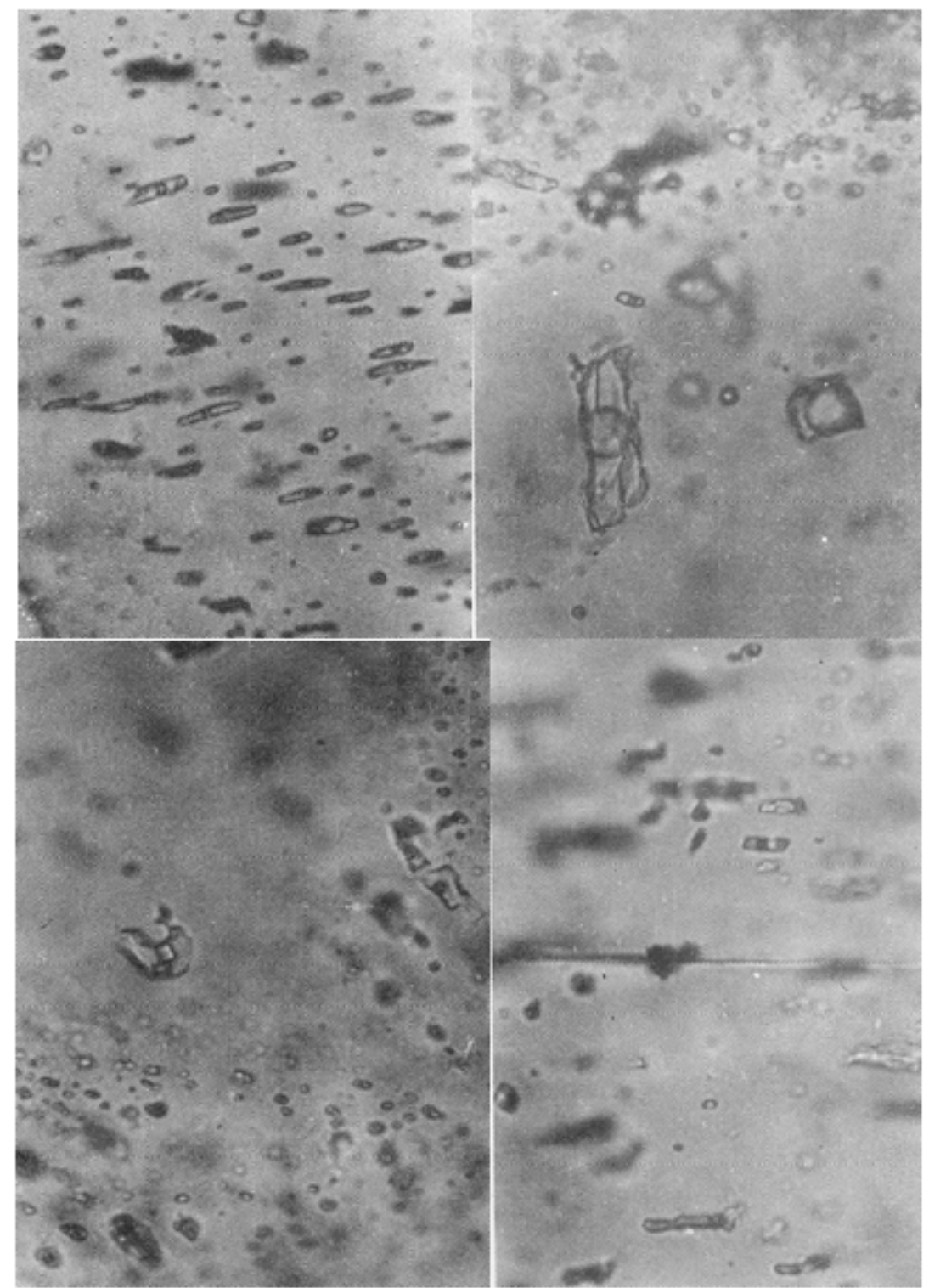

Figure 9: Fluid inclusions in quartz and calcite of the deposit. A: gaseous-liquid inclusions in quartz from \#I-4 Ore Body (X 400), B: gaseous inclusions in quartz from \#I-4 Ore Body (X 400), C: cubic NaCl crystal in gaseous-liquid inclusions in quartz from \#I-7 Ore Body (X 400), D: gaseous-liquid inclusions in calcite from coarse grained marble of the lower Triassic strata of the deposit (X 400).

correlate positively with homogenization temperatures (Table 2). Pressures of the series \#6 through \#9 samples in the table, acquired from minerals formed during tellurium mineralization, vary between 0.647-1.02 Kbar. This should be the pressure at which point telluride veins emplaced in the deposit. The corresponding mineralization depth is $4.08-2.16 \mathrm{~km}$, while mineralization temperatures of the early and late metallogenic epochs of the deposit are respectively $336.0-406.0$ and $216.9-229.0^{\circ} \mathrm{C}$. Fluid inclusion compositions in both pyrrhotite and pyrite that formed in the same mineralization stage of the metallogenic epoch are similar to each other. Those of fluid inclusions in quartz samples collected from the deposit are also alike. Compositions of fluid inclusions of dolomite and calcite have both similarities and differences, especially those of dolomite and calcite collected from outside the deposit compared to those collected within the deposit. Differences also exist between dolomite from wall-rock marble and from dolomite veins. This may mean that compositions of fluid inclusions vary from one host mineral to another, and minerals formed in different environments or across different geological events have different fluid inclusion compositions. The metallogenic hydrothermal solutions, which are not homogeneous, are richest in $\mathrm{SO}_{4}^{2-}$, richer in $\mathrm{H}_{2} \mathrm{O}$ than in $\mathrm{CO}_{2}$, rich in $\mathrm{Ca}^{2+}, \mathrm{CO}_{2}, \mathrm{H}_{2}$, and $\mathrm{CH}_{4}$, moderate in $\mathrm{Cl}^{-}$, but poor in $\mathrm{Mg}^{2+}$ and $\mathrm{F}$.

\section{Conclusion}

Based on the discussions above, preliminary conclusions of the Dashuigou independent tellurium mine's metallogenic conditions are summarized as follows: The metallogenic hydrothermal solutions are $\mathrm{SO}_{4}^{2-}-\mathrm{Ca}^{2+}$ type, or $\mathrm{SO}_{4}^{2-}-\mathrm{Na}^{+}-\mathrm{K}^{+}-\mathrm{Ca}^{2+}$ type, especially during the early metallogenic Pyritic Epoch, and $\mathrm{Na}^{+}-\mathrm{K}^{+}-\mathrm{Cl}^{-}$ $\mathrm{SO}_{4}^{2-}$ type during the late metallogenic epoch. The hydrothermal 
solutions of the deposit are mesothermal and of moderate salinity, as well as mesogenetic. Principal compositions of the metallogenic hydrothermal fluids are $\mathrm{Na}+, \mathrm{K}+,-\mathrm{Ca}^{2+}, \mathrm{Mg}^{2+}, \mathrm{SO}_{4}^{2-}, \mathrm{Cl}^{-}, \mathrm{F} \mathrm{H}_{2} \mathrm{O}, \mathrm{CO}_{2}$, $\mathrm{CH}_{4}, \mathrm{H}_{2}, \mathrm{~N}_{2}, \mathrm{CO}$ and $\mathrm{C}_{2} \mathrm{H}_{6}$; Salinity of the fluid inclusions within the metallogenic epochs varies between $13.8 \%-36.2 \%$, which falls into the medium-high salinity range; that of minerals formed during tellurium epoch, for instance, three quartz samples associated with tellurides and collected from \#I-4 Ore Vein in Table 2, is 14.9\%-18.7\%, which is within the medium salinity range. Metallogenic pressure is between $0.647-1.020 \mathrm{Kbar}$ and the corresponding mineralization depth is $4.08-2.16 \mathrm{~km}$. Mineralization temperatures of the early and late metallogenic epochs of the deposit are respectively 336.0-406.0 and $216.9-229.0^{\circ} \mathrm{C}$.

\section{Acknowledgement}

Support for this study was received from the China National Postdoctoral Foundation, Orient Resources Ltd., and Bureau Veritas Commodities Canada Ltd. Additional support was provided respectively by Prof. R. Pei of the Chinese Academy of Geological Sciences, also an Academician of the Chinese Academy of Engineering, Prof. Y. Zhai of China University of Geosciences in Beijing, also an Academician of the Chinese Academy of Sciences, Prof. J. Zhou of the Chinese Academy of Geological Sciences, and Prof. Y. Zhang of the College of Earth Sciences, Jilin University in Changchun of China, all of whom provided insightful discussions and critical reviews of this manuscript. All measurements and chemical analyses, including the back scattered electron (composition) and Te Ka X ray images of the thin section from the deposit, included in this article were carried out in the labs of the Chinese Academy of Geological Sciences in Beijing. The authors very much appreciate the time invested respectively by D. S. Yin and S. Daly, for their review and editorial work on this contribution.

\section{Data Availability}

The data that support the findings of this study is available from the authors upon reasonable request; see authors' contributions for specific data sets below.

\section{Contributions}

The whole research included in the paper was proposed and done by the first author J. Yin. The chemical compositions of fluid inclusions were sorted and researched by the second author Hongyun Shi of this paper. Both authors prepared and reviewed the manuscript and approved the final version of the manuscript. Author Contributions. Conceptualization, JIANZHAO YIN; Investigation, JIANZHAO YIN and Hongyun Shi; Project administration, JIANZHAO YIN; Writing - original draft, JIANZHAO YIN.

\section{Competing Interests}

The authors declare no competing interests.

\section{References}

1. Li T (1976) Abundance of chemical elements in the Earth. Geochemistry 3: 167-174.

2. Yin, JZ, Chen, YC, Zhou, JX (1995) Introduction of tellurium resources in the world. Journal of Hebei College of Geology 18: 348-354.
3. Yin, JZ (1996) On the metallogenic model and mineralizing mechanism of the Dashuigou independent tellurium deposit in Shimian County, Sichuan Province, China-the first and only independent tellurium deposit in the world. Chongqing: Chongqing Publishing House, 190pp.

4. Chen YC, Mao JW, Luo YN, Wei JX, Cao, ZM. (1996) Geology and Geochemistry of the Dashuigou tellurium (gold) deposit in Western Sichuan, China. Beijing: Atomic Energy Press 146pp

5. Luo, YN, Fu DM, Zhou, SD (1994) Genesis of the Dashuigou tellurium deposit in Sichuan Province of China. Bulletin of Sichuan Geology 14: 101-110.

6. Luo YN, Cao ZM, Wen, CQ (1996) Geology of the Dashuigou independent tellurium deposit. Chengdu: Southwest Communication University Publishing House 30-45.

7. Yin JZ (1996) The metallogenic model and mineralizing mechanism of the Dashuigou independent tellurium deposit in Shimian County, Sichuan - the first and only independent tellurium deposit in the world. Acta Geoscientia Sinica special issue 93-97.

8. Yin JZ, Shi HY (2019) Nano effect mineralization of rare elements--taking the Dashuigou tellurium deposit, Tibet Plateau, Southwest China as the example. Academia Journal of Scientific Research 7: 635-642.

9. Wang RC, Lu, JJ, Chen XM (2000) Genesis of the Dashuigou tellurium deposit in Sichuan Province, China. Bulletin of Mineralogy, Petrology and Geochemistry 4: $348 \sim 349$.

10. Cao ZM, Luo YN (1994) Mineral sequence and ore genesis of the Sichuan telluride lode deposit in China. In: New Research Progresses of the Mineralogy, Petrology and Geochemistry in China. Lanzhou: Lanzhou University Publishing House pg: 476-478.

11. Cao ZM, Wen CQ, Li BH (1995) Genesis of the Dashuigou tellurium deposit in Sichuan Province of China. Science China (B) 25: 647-654.

12. Yin, JZ, Zhou JX, Yang BC (1994) Geological characteristics of the Dashuigou tellurium deposit in Sichuan Province, China. Earth Science Frontiers 1: 241-243.

13. Yin, JZ, Chen, YC and Zhou, JX (1995) Original rock of the host rock of the Dashuigou independent tellurium deposit in Sichuan Province, China. Bulletin of Mineralogy, Petrology and Geochemistry 2: 114-115.

14. Yin JZ, Chen YC, Zhou JX (1996) Geology and geochemistry of host rocks of the Dashuigou independent tellurium deposit in Sichuan Province, China. Journal of Changchun University of Earth Sciences 26: 322-326.

15. Yin JZ, Chen YC, Zhou JX (1996) Geology and geochemistry of altered rocks of the Dashuigou independent tellurium deposit in Sichuan Province, China. Journal of Xian College of Geology, 18: 19-25.

16. Chen YC, Yin JZ, Zhou JX (1994) The first and only independent tellurium ore deposit in Dashuigou, Shimian County, Sichuan Province, China. Sci. Geol. Sinica 3: 109-113.

17. Chen YC, Yin JZ, Zhou, JX (1994) Geology of the Dashuigou independent tellurium deposit of Sichuan Province. Acta Geoscientia Sinica 29: 165-167.

18. Yin JZ, Zhou JX, Yang BC (1994) Rock-forming minerals and ore-forming minerals of the Dashuigou tellurium ore deposit unique in the world - A preliminary study. Sci. Geol. Sinica 3: 197-210.

19. Yin, JZ, Chen YC, Zhou JX (1994k) Mineralogical research of the Dashuigou independent tellurium deposit in Sichuan Province, China. Bulletin of Mineralogy, Petrology and Geochemistry 3: 153-155.

20. Yin JZ (1996) New mineralogical data of telluride. Bulletin of Mineralogy, Petrology and Geochemistry 15: 246-248.

21. Liu AP, Zhong ZC, Tang JW (1996) Geochemical characteristics of the Dashuigou tellurium deposit in Sichuan Province of China. Geochemistry 25: 365 371.

22. Shi HY, Chen YC, Yin JZ, Zhou JX (1996) X-ray diffraction data of telluride. Journal of Mineralogy and Petrology 16: 31-33.

23. Yin JZ, Shi HY (2020) Mineralogy and stable isotopes of tetradymite from the Dashuigou tellurium deposit, Tibet Plateau, southwest China. Scientific Reports 10.

24. Yin JZ, Chen YC, Zhou JX (1995) K-Ar isotope evidence for age of the first and only independent tellurium deposit. Chinese Science Bulletin 40: 1933-1934.

25. Li BH, Cao ZM, Wen CQ (2000) Fluid inclusion type and geological characteristics of the Dashuigou tellurium deposit in Sichuan Province, China. Bulletin of Mineralogy, Petrology and Geochemistry 4: 346-347. 
26. Li TY, Liu JQ (2000) Discussion of analytical methods of grouped fluid inclusion compositions. Geology and Mineral Resources of South China 4: 64-67.

27. Li BL (1986) Physical chemistry diagram of gas components of fluid inclusions in minerals. Geochemistry 2: 126-137.

28. Chen PR, Lu JJ, Wang RC (1998) Study on the fluid inclusions of the Dashuigou independent tellurium deposit in Shimian County, Sichuan Province, China. Mineral Deposit 17: 1011-1014.
29. Li BH, Cao ZM, Jin JF, Wen CQ (1999) Physicochemical conditions of the tellurium deposit in Dashuigou, China. Scientia Geologica Sinica 34: 463-472.

30. Wang RC, Shen WZ, Xu XJ, Lu JJ, Chen XM, et al. (1995) Isotopic Geology of the Dashuigou tellurium deposit in Sichuan Province, China. Journal of Nanjing University (Natural Sciences) 31: 617-624.

31. Shen WZ, Xu XJ, Wang RC (1997) Origin of the fluid inclusions of the Dashuigou tellurium deposit in Sichuan Province, China - hydrogen and oxygen isotope evidence. Journal of Nanjing University (Natural Sciences) 33: 77-83.

\section{Citation:}

Yin J, Shi H (2021) Fluid Inclusions and Metallogenic Conditions of the Dashuigou Tellurium Deposit, Tibet Plateau, Southwest China. Geol Earth Mar Sci Volume 3(3): $1-15$. 